\title{
Applying Target Costing to the Service Sector: Sunline Auto Insurance Case
}

\author{
James Wakefield* \\ Accounting Discipline Group, UTS Business School, University of Technology Sydney, \\ Australia \\ James.Wakefield@uts.edu.au \\ Paul Thambar \\ Department of Accounting, Monash University, Australia \\ Paul.Thambar@monash.edu
}

Running head: Applying target costing to the service sector

\section{Acknowledgments}

We appreciate the comments on an earlier version of this manuscript from participants at the Teaching and Learning Symposium held alongside the American Accounting Association's Management Accounting Section conference in Puerto Rico in January 2017. We thank the editor, the associate editor, and the reviewers for their valuable comments and suggestions. We thank Kenneth Merchant for his valuable comments and suggestions. We are grateful to our Monash University accounting colleagues Christo Karuna and Ahmed Sujan for their help in testing the case and providing useful feedback and comments. We also acknowledge the help provided by Eka Tan and the instructors, and their students in the Department of Accounting, Monash University, who tested the case and completed a feedback survey on it.

\footnotetext{
*Corresponding author:

James Wakefield

UTS Business School

University of Technology Sydney

PO Box 123

Broadway NSW 2007

Phone: +61295143583

Fax: +61 295143669

Email: James.Wakefield@uts.edu.au

ORCiD: http://orcid.org/0000-0001-7269-0141
} 


\title{
Applying Target Costing to the Service Sector: Sunline Auto Insurance Case
}

\begin{abstract}
The application of target costing in a service firm is rarely taught in managerial accounting courses, in contrast to the focus on manufacturing-related cost topics (e.g., Everaert \& Swenson, 2014). Educating future managers in the use of service-sector target costing is important because it provides knowledge on how profitability can be improved through a considered approach to cost management. The case study objectives are to improve students' ability to analyze and explain important areas of cost, assess and apply target costing, and strategically consider costs. Our testing indicates support for case efficacy in the context of these objectives. The case refers to an auto insurance firm to illustrate how target costing can be applied in the service sector. Students are provided with information on cost data and the target costing technique, allowing them to assess costs, apply the target costing techniques, and develop strategic cost management focus and recommendations.
\end{abstract}

Keywords: strategic cost management, target costing, service firm costing

JEL classification: A22 


\section{THE CASE}

\section{Background and Strategy}

Janet Preston, business manager of Sunline Auto Insurance ${ }^{1}$ based in Los Angeles, is in her office on a bright Monday morning in January reviewing the monthly performance report. Janet has been working at Sunline for six months. She is worried as she reviews the performance of Sunline for the fourth quarter of the previous year (October to December). The report shows that while sales grew so did losses.

Janet is aware that the competitiveness of the auto insurance sector has increased substantially and that low interest rates have placed downward pressure on cash returns and margins. She realizes that Sunline's losses are in line with similar trends in the auto insurance sector, but Janet is still concerned about the losses, since she has direct management responsibility for the performance of Sunline. Her manager at the parent company, Palm Investments (Palm), is also beginning to question Sunline's performance.

\section{[INSERT TABLE 1 HERE]}

Sunline is wholly owned by Palm, headquartered in San Francisco; Palm owns eight other companies in the finance and insurance sectors. Sunline operates as a stand-alone company, with Janet Preston having significant autonomy to develop, promote, and sell products and manage the activities of Sunline. Headquarters provides legal and compliance advice to the subsidiaries and ultimately closely monitors each subsidiary.

The high rates of motor vehicle ownership in California, relative to other states, means there are high numbers of insurance policies. Statistics from the U.S. Census Bureau shows in some parts of California vehicle ownership is as high as 9.7 cars for every 10 adults. Injury and

\footnotetext{
${ }^{1}$ All company and staff names are fictional. The company does not specifically represent one real life business; the case is based on the experience of the authors across the insurance sector.
} 
property damage insurance is required in California by law. Sunline was established five years ago and entered a market where customers are quite sensitive to the prices they pay for auto insurance policies. Therefore, customers shop around for the lowest price and are very selective about the features of the policies. The way insurance policy products are positioned in the market to acquire market share is therefore very important. Since being established, Sunline has grown its market share and customer base consistently in Los Angeles.

Sunline focuses solely on a unique product called Ride Cover, specifically targeted at car enthusiasts with unique cars (e.g., classic, customized, and modified cars). The product packages the compulsory insurance coverage (based on minimum legal requirements in California $^{2}$ ) with comprehensive and collision insurance. The focus on customers with unique cars also means Sunline is less likely to be impacted by the emergence of autonomous cars, reducing demand for insurance products. Ride Cover offers unique benefits, including full replacement value, a loan car with no mileage limit while the owner's car is off the road for repair, the owner's choice of repairer, and unlimited roadside assistance in the event of a breakdown. The choice of repairer particularly appeals to customers who have spent a significant amount of money and time restoring, customizing and modifying their cars. The aged, customized and modified nature of these cars also means mechanical problems are likelier, and accordingly customers place great value on unlimited roadside assistance. Customers can also opt for higher levels of injury and property coverage beyond that required in California and lower deductibles as part of the Ride Cover policy.

Ride Cover can be acquired by customers through Sunline shop fronts (in major shopping malls such as the Glendale Galleria, South Coast Plaza, and the Beverley Center), Sunline's website, and Wells Fargo banks. The company has pop-up stalls at motoring events

\footnotetext{
${ }^{2}$ See http://www.dmv.org/ca-california/car-insurance.php
} 
(including the annual L.A. Auto Show and various Cars and Coffee meets) to specifically target car enthusiasts. At each of these venues, representatives from Sunline are available to provide customer service, including assessing customer needs, answering inquiries, explaining pricing policies, and providing general support to new and existing customers. The use of multiple distribution channels provides customers with easy access to Ride Cover.

\section{Product Costing and Strategy}

Sunline operates a "cost-plus" product costing and pricing strategy, which has been in place since establishment five years ago. The cost-plus pricing model assumes customers are willing to accept a reasonable level of pricing for the insurance product. Essentially, the cost associated with all operations are added up, referring to actual and budgeted costs, and averaged across the number of estimated policies sold in the period. An average target profit margin is then added to the average costs in order to price the product. This creates an "average target profit margin" as product pricing is determined largely by an individual customer's risk profile and government insurance pricing regulations. Accordingly, policy pricing differs for each customer.

Table 2 outlines the costs for Sunline. Each of the cost areas and the association with Sunline's strategic positioning are explained below.

\section{[INSERT TABLE 2 HERE]}

Salaries and wages relate to underwriting salaries, underwriter incentives, claims and administration staff, marketing, and management staff salaries. Underwriting is a key activity in an insurance business and focuses on assessing the "insurable risks" on behalf of the business, determining if the risks can be insured, and if so, at what price or premium. This activity is related to but different from selling insurance policies, which is usually carried out by brokers or agents of the insurance business. Brokers or agents act on behalf of one insurance 
business or may work across multiple insurance businesses. They do carry out some assessment of "insurance risks" before recommending insurance products, but this assessment of risk is in addition to and separate from the underwriting assessment.

The insurance company assesses the likelihood of claims being made on each of the insurance products sold and provides a reserve to cover these claims. These reserves are funded through investment earnings, operating profits, and, at times, capital from investors. The assessments of how much to reserve and how to fund the reserves are carried out by actuarial staff in consultation with underwriters, brokers or agents, and claims and accounting staff. All claims, particularly those that are not fully reserved, don't need to be processed through the reserve, and the cost of a claim can also be directly expensed to the current year's profit and loss statement. The processing of claims received is carried out by claims staff who have expertise in assessing claims, carrying out investigations of facts related to the claims, and making decisions on which claims to accept or reject.

Historically Sunline has sold 60 percent of new policies in-store (Sunline stores and Wells Fargo bank branches) and the remaining 40 percent online. The in-store sales proportion is relatively high, primarily because customers want to discuss their requirements in more detail with underwriting staff given the unique nature of their cars. Some customers, particularly more mature-aged customers, are less comfortable about purchasing policies online. There are also some customers who go to the store to renew their policy; this takes staff time away from selling new policies. Despite this, there are concerns as to whether underwriters are sufficiently motivated - they appear to be selling far less than the target of 20 new policies per week-a target agreed upon by Janet, her leadership team, and the underwriting team. In addition, claims and administration staff have a target of resolving ten claims per week; however, there is currently no incentive scheme to motivate staff to achieve this target. 
Staff knowledge of the Ride Cover policy is very important so they can explain to customers its unique features. In addition, it is important that claims management staff are equipped with the knowledge to deliver on the policy promises and to ensure customers are satisfied. Customer satisfaction is very important because many customers are members of automotive clubs and convey their opinions about the Ride Cover policy to fellow club members, particularly if they have a bad experience. Sunline therefore worked with a training company to develop a program to train new underwriting and claims management staff. The program is costly- $\$ 4,750$ and $\$ 3,250$ for each underwriting and claims management staff member respectively_ but Janet considers it worthwhile to deliver on the company's sales positioning and customer promise. While the cost of training is considerably lower than some of the other cost areas, staff turnover is still relatively high at 30 percent per annum. Janet wants to reduce this turnover as more experienced staff are more knowledgeable and can deliver a better customer experience as well as reduce staff training costs.

The marketing costs are considerable. Janet believes marketing is important to convey the unique features of the Ride Cover policy. However, headquarters has expressed concern with the effectiveness of the marketing spending and whether Sunline is realizing the full impact expected from the marketing campaigns. For example, while television campaigns are strategically placed in automotive-related shows, television audiences are in decline, and it is not clear whether viewers pay attention to these advertisements anymore. The cost of billboard advertising across California is very high. However, it is unclear whether the spending on billboard advertising is having the desired impact on sales. Janet is considering whether it would be better to have more focused marketing campaigns. For example, greater representation at automotive club meets, sponsorship of automotive clubs, and advertising in automotive magazines and online via social media may have greater reach and reduce outlay. 
The cost associated with technology is relatively minor. These costs relate to the new media platform, cloud-based database systems, and related data analytics, which are increasingly used to understand customer behavior, predict future sales, market share, and insurance claims. The increased use of technology at Sunline has not been accompanied by improvements in operational efficiency and effectiveness. Since joining Sunline, Janet has believed that operations require a transformation project to leverage the benefits of technology through efficiencies in processes and staffing. Another important technology-related cost is the company's website. Improvements in the website, including ease of navigation and transaction completion, may not only increase overall online sales, but may also mean customers are less likely to go to a Sunline store to purchase or renew a policy. This could therefore considerably reduce salaries and commission to underwriting staff and the need for physical stores.

While Sunline retail stores are relatively small, their presence in large and busy shopping malls and villages means the lease costs are high. Janet has discussed with her management team whether leasing stores in more expensive locations is necessary given that customers almost never purchase insurance policies on impulse, but rather investigate, consider, and plan which policy they intend to purchase and make their decision beforehand. This is likely to be the case particularly for automotive enthusiasts, who are Sunline's key target market. Accordingly, renting lower-cost stores on retail strips that are considerably cheaper and offer easier parking may be a more cost-effective option.

Insurance claims are another sizable cost item for Sunline. Providing the owners with a choice of repairer drives up the cost of repairs considerably as auto body shops deal individually with customer requests. There has been some discussion as to whether to adopt an approach in line with other insurers, where the insurance company manages the whole repair process. For example, the damaged car is taken to the insurance company's assessment center 
and grouped with other cars; then, through a tender process, cars are distributed in batches to auto body shops for collision repair. However, it appears customers value the choice of repairer option highly and moving away from this feature would undermine the competitive advantage of the Ride Cover product. The cost of roadside assistance is also considerable, but it is an important product feature for the target market. Sunline outsources this service to a series of roadside assistance partners operating across the state of California.

The last two costing items are headquarters charge back and interest earnings. The total cost of operating the headquarters is charged back to the eight subsidiaries. To keep matters simple, headquarters charge back one-eighth of the cost to each of the eight subsidiaries. Janet is not convinced the simple allocation basis matched the actual level of services and transactions at Sunline. This allocation method has caused some tension between the different subsidiaries. However, Janet has not yet felt she is in a good position to negotiate what she believes to be a fairer allocation given she has only been with Sunline for six months. The interest earnings are based on the interest paid on cash holdings set aside for the provision of future insurance claims.

Table 3 sets out the key financials relating to the cost-plus pricing approach used for the Ride Cover policy. These financials relate to quarter four and show the average premium revenue and costs per policy on a quarterly basis. The loss per policy is $\$ 77.59$, based on an average policy cost of $\$ 377.59$. Due to market pressure, including customers threatening to take their business elsewhere, the average premium is $\$ 300$, inconsistent with the cost-plus approach.

[INSERT TABLE 3 HERE] 


\section{Strategic Cost and Revenue Management}

As Janet reviews the performance in the last quarter, it becomes clear the current revenue and cost strategy based on a cost-plus approach is not sustainable. Customers are not willing to pay the cost-plus price. She recalls reading an article on target costing (TC), which is a strategic cost and revenue approach for improving product sales through a more strategic view of customers' preferences and needs. Janet wonders if she can develop a position paper on TC to demonstrate to headquarters how Sunline could strategically prioritize costs and manage down costs not closely associated with the competitive positioning.

As she recalls, TC focuses on the price the customer is willing to pay for a product and enables a firm to reverse engineer its product cost structure based on this target price. A firm estimates the target price by carrying out market analysis to understand what features of the product are attractive to the customer and how much customers are willing to pay for each feature. Once a target price is determined, the firm takes the profit margin away to arrive at a target cost. This cost is labeled the "allowable cost," which usually is lower than the current product costs within the firm. The firm then has to carry out cost management activities and strategic realignment to bring the current product costs down to the target cost (allowable cost) over a period of time.

Table 4 sets out the pricing for Ride Cover if it is based on a TC approach. Current market research suggests the average premium for a policy needs to be set at an average of $\$ 300$ (based on the current average quarterly premium actually charged) to maintain current sales volume and market share. Based on earning a profit margin of 10 percent, the allowable cost of a policy needs to be set at $\$ 270$ - this requires a 28 percent reduction in the current product costs of Ride Cover. 
Well established in Japanese firms, TC has traditionally been neglected in Western firms as it requires significant shifts in management and culture to be successful. However, Janet feels it is a useful approach for Sunline to consider and begins to gather information to develop a paper on TC. She considers some key issues: what is the process of TC, and how can it be adapted for auto insurance products? What would the changes be to operational priorities and management processes when moving Sunline from a cost-plus pricing strategy to a strategic revenue and cost management strategy such as TC? What key steps should Janet propose to improve performance using TC?

\section{Class Requirements}

This case has been developed to improve your understanding of strategic cost management using a specialist technique known as TC. Traditionally an approach such as costplus pricing is used where the core assumption is that customers accept any price determined by the firm. However, if customers show an inclination to resist the price set by the firm, the firm could resort to cost cutting and lowing prices. This case shows a strategic approach by starting with the price the customer is willing to pay for the product or service features and then arriving at a product cost that is allowable. Once you have read the case, address the following case questions.

1. Describe the general competitive environment of the auto insurance industry.

2. Describe and explain cost-plus pricing in a service firm context, specifying cost categories and their influence on pricing.

3. Explain the key steps involved in TC. Use Table 4 as the basis for your discussion.

4. Assess the specific challenges of introducing TC in a service firm as opposed to a manufacturing firm. How should TC be adapted in a service firm? 
5. How would you improve the profitability of Sunline? Evaluate specific steps you would consider. Focus on the costs currently incurred and how they could be reprioritized and cut to meet the target cost, in line with the current competitive positioning. Use the information in tables 2-4 to illustrate and justify your answer.

6. Evaluate and explain the key challenges (cultural, management systems, information needs, etc.) involved in implementing a TC approach at Sunline. 


\section{CASE LEARNING OBJECTIVES AND IMPLEMENTATION GUIDANCE}

\section{Introduction}

Globally the service sector has experienced significant growth and increased competitiveness enabled by advances in telecommunication technologies (Mansury and Love 2008). This puts considerable pressure on service firms to price products competitively, often relying on accounting graduates to apply value-relevant techniques to achieve their objectives. Target costing (TC) is not a new technique, and there is considerable literature in the area, certainly from a teaching-case perspective, in the context of manufacturing organizations (Cooper and Slagmulder 1999, Everaert and Swenson 2014). Surprisingly, given the price and cost pressures, there are few cases applying TC to the service sector.

The purpose of this case is to specifically introduce and develop students' understanding of strategic cost management using a specialist technique known as target costing (TC) in the context of the service sector. Most managerial accounting courses traditionally focus on approaches such as cost-plus pricing where students are taught to develop costs from inputs to the production process, to add on a product profit margin, and to price a product. The case develops students' detailed knowledge of TC, helps students to critically evaluate how and why the technique should be applied to different firms, and develops students' ability to think more creatively about such techniques and cost management. There are numerous calls for accounting students to develop a range of work-ready skills, including critical thinking, creativity, and communication (Bolt-Lee and Foster 2003, Holtzman 2004, Gazzaway, Kim, Malinconico, and Newport 2010), and the application of an established technique to an alternative context is associated with the development of such skills. The intended audience of this case is students studying managerial accounting courses in graduate 
business degrees and in advanced managerial accounting courses in undergraduate business degrees.

The three specific learning objectives are to:

1. Analyze and explain the important areas of cost in a service firm.

2. Assess and apply TC to a service firm.

3. Evaluate and assess the important firm costs in the context of competitive positioning and competitive advantage.

The questions for students to address after reading the case are mapped to these objectives in table 5, below.

[INSERT TABLE 5 HERE]

\section{Teaching Approach}

In this section, we first explain a teaching plan implemented in the undergraduate and graduate cost management courses at the university where the case was tested. This plan is specifically tailored to the classes scheduled (lecture and tutorial format), associated class lengths, and assessment structure of these courses. The teaching plan for the undergraduate and graduate course is provided in appendix 1.

Given the focus on cost-plus pricing rather than TC in managerial accounting courses, we suggest students complete background reading on TC prior to commencing the case. This can be achieved by asking students to complete relevant text chapter readings on $\mathrm{TC}$ or alternatively referring them to the three materials listed below. These materials are useful in illustrating TC in a manufacturing context, which can then be contrasted with the service context of Sunline Auto Insurance.

1. Cooper, R., and R. Slagmulder (1999). Develop profitable new products with target costing. MIT Sloan Management Review 40 (4): 23 
2. Everaert, P., and D. W. Swenson (2014). Truck redesign case: Simulating the target costing process in a product design environment. Issues in Accounting Education 29 (1): $61-74$.

3. Everaert, P., S. Loosveld, T. Van Acker, M. Schollier, and G. Sarens (2006). Characteristics of target costing: theoretical and field study perspectives. Qualitative Research in Accounting and Management 3 (3): 236-263.

Because the automotive insurance industry is a unique sector, background reading can help students better understand its characteristics and how these characteristics relate to the case organization. To gain insight into the current state of the insurance industry, particularly the challenges of increased costs and associated trends (Hartwig, Lynch, and Welsbart 2016), and the emerging trends that warrant medium- to long-term consideration (Albright, Bell, Schneider, and Nyce 2015), we suggest students read the following white papers:

1. Hartwig, R. P., J. Lynch, and S. Welsbart (2016). Personal automobile insurance: More accidents, larger claims drive costs higher. New York, Insurance Information Institute. URL: https://www.iii.org/white-paper/personal-automobile-insurance-more-accidents$\underline{\text { larger-claims-drive-costs-higher-101716 }}$

2. Albright, J., A. Bell, J. Schneider, and C. Nyce (2015). Marketplace of change: Automobile insurance in the era of autonomous vehicles. KPMG. URL: https:/home.kpmg.com/content/dam/kpmg/pdf/2016/05/kpmg-automobile-insurancein-era-autonomous.pdf

We suggest students be directed to complete the readings, including the Sunline case, prior to the lecture in undergraduate and graduate courses. This is estimated to take students two and half hours (item one in appendix 1). The lecture that follows these readings can then 
review the fundamental concepts related to TC and how TC compares with other strategic cost management systems and techniques. It is also important to contextualize the content in the Sunline case as part of the strategic cost management lecture (item two in appendix 1), and to remind students the case will be the focus of the following tutorial.

The case questions are the same across the undergraduate and graduate courses (item three in appendix 1), and we suggest the case questions are completed by students prior to the tutorial. However, the tutorials are differently organized at the undergraduate and graduate levels, with the exception of introduction and final class discussion (items four and seven in appendix 1). Both items four and seven are kept short to maximize the opportunity for in-depth case discussion and associated student participation. At the undergraduate level, a group of five students is preassigned to initially present the case and their perspectives related to the six case questions, in association with a report they also complete based on their reading and consideration of the case. As part of this presentation they are to provide opportunity for class participation, allowing students not in the presenting group to share their perspectives, and the instructor facilitates this participation where required (item five in appendix 1). Students who are not presenting the case and associated questions are expected to participate. Students are graded on their participation in class (10 percent of their course assessment) and also on reflective notes they are to complete consistent with their answers to the homework questions (also a further 10 percent of their course assessment). Such assessment is designed to ensure all students read and thoroughly prepare their answers to the homework questions. Based on the instructors' feedback and observations, students actively participated in class, adding to and sharing alternative perspectives as part of the group's presentation, consistent with the incentives provided by the assessment structure. 
At the graduate level, there is no one group assigned to deliver a presentation. Instead the instructor is to actively facilitate students' answers, perspectives, and discussion, ensuring that participation is managed such that the case questions are sufficiently covered based on input from all students in the class. Similar to the undergraduate course, students are graded on their participation in class (10 percent of their course assessment) and know they will be specifically called on, where required by the instructor, to participate. Given graduate students' longer period of study and higher levels of experience, it is expected they generally have the ability to drive class discussion concerning the case beyond that of the undergraduate students. For this reason, the graduate tutorial is completely reliant on student participation, whereas the undergraduate tutorial, while still expecting all students to participate, has the group presenting to help drive class participation and discussion.

There is likely to be a wide diversity of student views, opinions, and ideas relating to case questions five and six (item six in appendix 1). As part of completing case question five, we recommend students use spreadsheet software, such as Microsoft Excel, to illustrate their answer relating to ways to reduce cost. Using a spreadsheet program should also make it easier for students to discuss and present their answers in class. There is a range of programs that enable capture, annotation, and display on classroom projection systems (e.g., Wakefield, Frawley, Tyler and Dyson, 2018) to help facilitate students' discussion of their answers in class. Instructors may wish to modify case question five to direct students to use spreadsheet software, depending on students' access to technology outside and inside the classroom.

For students' participation and discussion related to case question five and six (item six in appendix 1), we expected that graduate students, particularly those with practical accounting experience, would have many views, opinions, and ideas to discuss and points to consider for this part of the class. We also considered it likely that graduate students would spend more time 
discussing and presenting the challenges of implementing TC, while undergraduate students would likely spend more time on ideas to reduce costing. However, contrary to our initial expectations, there was not a clear difference between undergraduate and graduate students' participation concerning their answers for case questions five and six. At the institution in which the case was used, there is considerable variation in students' prior studies and workplace experience within both the undergraduate and graduate programs. This difference in academic and workplace experience had a noticeable effect on the quality of focus, attention, and response to the case's requirements. Those with broader, deeper study experience (for example, students who had considered a wider range of topics as part their studies) and had more workplace experience were far likelier to be aligned with our initial expectations of graduate students. Those with more limited prior studies and little, if any, substantial workplace experience were more aligned with our initial expectation of undergraduate students. Therefore it is important for the instructor to evaluate the individual students' experience, whenever possible, to effectively consider the most appropriate delivery and facilitation of the case.

A final class discussion facilitated by the instructor is recommended, item seven in appendix 1 , focusing on the value relevance of $\mathrm{TC}$ to the service sector and any remaining issues to be covered. We recognize there is variation in the class structure and delivery of courses at different institutions, and accordingly these teaching plans will need to be adapted where relevant, as we suggest below. We believe it is important we present the approach of delivering the case above, as this allows the contextualization of the case efficacy explanation following this section.

We propose two alternative teaching plans. First, a three-hour seminar format class, provided in appendix 2 . The readings and case homework questions are consistent with the lecture and tutorial class structure plan provided above. However, the three-hour seminar 
format provides more flexibility in the organization of the class. We suggest small-group breakout sessions for students to discuss case questions five and six (items seven and eight in appendix 2). It is important to specify a maximum presentation time for discussion of items seven and eight, to keep discussion focused, and to provide all groups with the opportunity to present during class time. We suggest groups have the opportunity to share their ideas, perspectives, and views with the class (item nine in appendix 2). The presentation not only facilitates idea sharing, but also motivates group members to conclude on a holistic set of perspectives and ideas during class time. We have also developed a teaching plan for an online class, provided in appendix 3. Given the challenges associated with generating in-class discussions online, instructors will need to play a more direct role in highlighting the key points of the case. Given the case emphasizes the sharing of perspectives, views, and opinions, particularly concerning the means of improving profitability and the challenge of applying TC, a means of organizing student interaction through an online platform or other collaborative communication technology is a crucial substitute for in-class discussions.

\section{Case Efficacy}

The case was first presented at a management accounting academic conference and was provided to instructors at the institution where it was tested. Feedback was received and associated revisions were made to the case, which was then tested in the spring 2017 semester of two courses: an advanced managerial accounting course in the third year of an undergraduate degree in accounting; and a strategic managerial accounting course in the second year of a master's, graduate, degree in professional accounting at a large metropolitan university.

A survey was conducted before and after case completion. Students were asked to indicate their level of knowledge of TC and their perceptions of the case based on a five-point Likert scale (strongly agree-strongly disagree). The survey questions and associated data are 
provided in tables 6 and 7 . All students in the two courses where the case was tested completed the survey, providing a usable set of 152 and 320 responses from the undergraduate and graduate students respectively. ${ }^{3}$

\section{[INSERT TABLE 6 \& 7 HERE]}

Students indicated significantly higher agreement for the post-case completion survey compared with the pre-case completion survey questions (based on the mean difference T-test ${ }^{4}$, reported in the last column of tables 6 and 7), recognizing the important areas of cost for a service firm, the purpose of TC, applying TC, and creatively considering service business costs (questions 1-4). This provides support for the efficacy of the case in the context of the learning outcomes. It is interesting to note while there are statistically significant increases in agreement and very similar post agreement for undergraduate and graduate students, the absolute increase in agreement for graduate students is higher.

The greater increase in learning outcome agreement indicates that graduate students may be more conservative in indicating their level of prior understanding and that their higher level of practical experience means they learned more through the case. In addition, a further explanation is students' greater opportunity to participate in class because of the longer allocated tutorial time and the absence of a group assigned to present and drive class discussion, which means students prepared more thoroughly, found the class more productive, and therefore learned more. Discussions with instructors in both courses indicate there is considerably more opportunity for student participation in the graduate course. Accordingly,

\footnotetext{
${ }^{3}$ The authors were not involved in teaching these courses.

${ }^{4}$ The survey question data is normally distributed or close to normally distributed, appropriate for the T-tests. As a further test, the Wilcoxon signed ranks tests (which assumes non-normal data distribution) are also performed to test the mean difference. The results are consistent with the T-tests presented in this paper.
} 
the benefits of providing students with greater opportunity to participate and discuss indicates the small breakout group discussion in the three-hour seminar plan may enhance learning.

Students perceived the case to be a valuable learning resource (questions 5-10). In the post-case completion survey, students indicated high levels of agreement that the case is interesting, realistic, and relevant. They also indicated high levels of agreement for recommending the case as part of the course in the future and as a valuable learning experience. Consistent with the larger increases in pre- and post-case agreement for the graduate students compared with undergraduate students, graduate students also indicated higher levels of agreement associated with the learning experience. For the question relating to the case difficulty, students indicated moderate levels of agreement, which implies that the case challenged them to think about target and service costs situations.

As a further test of the case's efficacy, we examined the learning outcomes of students assigned to present the case in the undergraduate course. While all students were required to participate in the class and complete the homework questions, the presenting groups were required to complete a report based on their reading and consideration of the case, followed by a group presentation to their class, accounting for 30 percent of their assessment. The undergraduate course was held across 12 weeks, and a different group of five students was randomly assigned each week to present the week's case and facilitate class discussion across eight tutorial classes in the course. Given the requirements of this assessment and the size of each group, we have considerable assurance that students in the assigned groups thoroughly read and considered the case and associated questions. Accordingly, we believe it is important to examine the learning outcomes for these undergraduate students who were assigned the group presentation in order to evaluate their learning outcomes in further depth. Consistent with our prior discussion, we believe there are no notable differences generally in the 
characteristics of the undergraduate and graduate students, and therefore we expected no notable differences in what they learned from the case.

To examine the learning outcomes, we conducted a pre- and post-case quiz (at the end of a class in hard copy) in the autumn 2018 semester. Identical questions were asked in each quiz. Students were informed these quizzes were voluntary and not related to their assessment in any way. The quiz questions are provided in tables $8-10$. The pre-case quiz was administered on a Friday, which preceded the release of the Sunline case on the following Monday. Students had 12 days from the Monday to the Friday in the following week to prepare their presentation and report based on their reading and consideration of the case. The post-case quiz was administered at the conclusion of the class where students had done the group presentation. Although the questions in the quizzes were identical, we have no reason to believe students specifically focused on memorizing or finding answers for the post-quiz because students were not informed that the post-quiz would be identical, they knew the quizzes would not count toward their assessment, and the completed pre-case quiz responses were collected at the conclusion of the class and therefore students did not retain a copy.

A total of 40 matched pairs of pre- and post-quizzes were received across the eight classes held in the course, indicating all students in the assigned groups of five students in each class completed the quizzes. The pre- and post-quiz contained a series of questions related to the three objectives of the case, with the results summarized in tables $8-10$. We first examined the efficacy of the case in the context of learning objective one, the ability of students to analyze and explain the important areas of cost in a service firm. The Wilcoxon signed ranks test based on two related samples (matched pairs) for question one-which were appropriate given sample sizes and nonparametric data—indicates a significant increase in students' recognition that "fixed costs" account for a significant proportion of the service firm's overall cost. 
However, a high percentage of students recognized "direct labor hours" are a sizable proportion of service firms costs compared with manufacturing firms pre-case and therefore no significant increase from the pre- to post-case quiz for question two is observed. Students were asked to rank the significance of costs in determining the total costs of a service firm compared with a manufacturing firm in question six. Based on Wilcoxon signed ranks test, the mean ranking was significantly lower for "cost of goods" (not as significant in determining total costs) and the mean ranking was significantly higher for "salaries and wages" (more significant in determining total costs). Neither the ranking for "marketing and depreciation and leasing equipment" significantly changed across the pre- and post-case quiz, consistent with no clear differences expected across service and manufacturing firms. Accordingly, based on the quiz responses, students appeared to be building up their existing understanding that direct labor is a significant determinant of service firm cost through indicating that "fixed costs" and "salaries and wages" are major drivers of service firm costs beyond their initial perceptions.

\section{[INSERT TABLES $8-10$ HERE]}

There was a significant increase in students' recognition that customer acceptance of any price set by the firm is problematic, based on question three, post-case completion. While there was an increase in students" correctly understanding the term "allowable costs" (question four), this was not a significant increase. A closer examination of the data revealed that 42.5 percent and 42.5 percent of students respectively recognized that allowable costs refer to "direct and overhead costs," and "direct costs, overhead costs and profit margin" in the precase quiz. In the post-case quiz 52.5 percent and 42.5 percent of students respectively recognized that allowable costs refer to "direct and overhead cost", and "direct costs, overhead costs and profit margin" respectively. It therefore appeared that the vast majority of students understood the concept pre- and most certainly post-case completion. While it is unlikely that 
students considered profit margin a cost, they perceived it is something that needs to be considered, consistent with target costing principles. Students' understanding of the initial application of TC, through focusing on price point, significantly increased (question five) postcase completion. This is consistent with the significantly elevated ranking of "determining the prices the market will accept" and the lower ranking associated with "calculating the total product cost," in question seven. Similarly, for open-ended question ten, all students post-case completion were able to identify, without prompting, that firms start the TC process based on market expectations and/or pricing. Accordingly, the pre- and post-quiz responses provided support for the case's efficacy concerning learning objective two, assessing and applying TC to a service firm.

There were no significant changes in the ranking of "prioritizing costs in the interests of delivering on competitive strategy" (question eight), although it did increase and was already relatively highly ranked at an average of 2.275 in the pre-quiz. A similar result was noted for "prioritizing different costs to deliver on competitive strategy" in question nine. However, when students had the opportunity to provide open-ended responses for questions 11 and 12 , they demonstrated a far better ability to assess the important costs in the context of competitive positioning and competitive advantage, explaining it is important to prioritize costs that focus on value generation and drivers for customers. Significant increases in the extent students focused on value generation and drivers were noted for question 11 and 12 when coded based on these attributes, a move away from general cost minimization strategies such as quality reduction and staff cuts identified in the pre-case quiz. Accordingly, these responses and results provided support for the efficacy of the case in the context of learning objective three, evaluating and assessing the important firm costs in the context of competitive positioning and competitive advantage. 
The instructor feedback on the case in the two courses was encouraging and positive. Instructors commented that the resources provided with the case (i.e., suggested readings, teaching plans, teaching notes, and solutions) were comprehensive relative to other cases, and they did not have any requests for additional resources when asked. As a result, instructors, in particular the graduate course instructor, indicated the case took less time to prepare than other cases they use. The instructor teaching the undergraduate course commented that the case was useful to teach students strategic cost management in a service environment. The case requires students to consider costs in a service environment, and to compare and draw out the differences between the service environment and a traditional manufacturing environment. This was found to be useful to help students to think about costs and cost behavior differently in different sectors, and in particular to consider how to manage costs in a strategic manner in this service environment. The following statement from an instructor is illustrative and illuminating: "My students, even before coming to class, emailed me and asked me questions on the case and on how to carry out the analysis. One student even identified that he had been unable to locate any other learning materials on target costing in a service firm and was excited that the topic and the case was included in the course."

In the graduate course, the instructor found the case very useful in getting students to think about revenue and cost management in a strategic manner. The following quote is illustrative:

[The] case gave me the scope to get the students to focus on strategic revenue and cost management. Even though target costing is a costing practice, its focus on starting with the customer and the product/service features, which are important to the customer and for which they are willing to provide value, helped me to engage my students in a class discussion on revenue growth and management and how target costing practices help a 
firm to consider these issues. It's an interesting case and very useful to teach and apply target costing practices in a service firm. 


\section{TEACHING NOTES}

This section contains suggested solutions and notes for each of the case questions. Please note there is an Excel spreadsheet relating to question five-how to improve profitability (discussed in the section below), which allows for development of alternative scenarios. A grading rubric is also included in Teaching Note - appendix 1 to provide guidance to instructors on how to grade the case submissions from students. Please note this example provides general guidance on the design of a rubric in the context of this case, as we expect instructors may need to adapt such a rubric on a case-by-case basis depending on the nature of the course and the requirements of their institution.

\section{Describe the general competitive environment of the auto insurance industry}

The economic environment in the US is gradually recovering from the 2008 global financial crisis and is showing important improvements in economic activity, job growth, and business confidence. While the political gridlock in Washington is expected to continue and remain challenging, the business outlook in general in the US is expected to maintain a steady upward trajectory.

Personal automobile insurance is among the best-known insurance products in the US. The US market for total personal automobile insurance premiums in 2014 was approximately $\$ 186$ billion, representing nearly 35 percent of the total property and casualty insurance premiums in that year. Personal automobile insurance premiums have grown at around 3.5 percent in the past three years. The US auto industry has recovered well from the 2008 global financial crisis and is expected to sell around 17 million new cars annually, which should drive positive growth in insurance premiums in personal auto insurance due to higher values on the road. The increase in insurance premiums in personal auto insurance is also driven by increases in insurance costs. In addition, firms like Sunline Auto Insurance are not making the same 
return on their investment of the insurance premiums paid and so are increasing premiums in order to compensate. Despite these increases, the auto insurance sector is generally loss making and has been for a number of years.

The personal auto insurance industry is facing disruption from new innovations (e.g., driverless cars), leading potentially to lower premiums. While these innovations are still scaling up and do not pose an immediate threat to the business model of car ownership and personal auto insurance, it is expected that in the medium- to long-term these innovations could change how personal auto insurance products are consumed. Further disruptive innovations such as ride-share firms (e.g., Uber) are also likely to provide new opportunities for personal auto insurance products.

Please note that in "case learning objectives and implementation guide" we recommend students read the following white papers to better understand the general competitive environment of the auto insurance industry:

1. Hartwig, R. P., J. Lynch, and S. Welsbart (2016). Personal automobile insurance: More accidents, larger claims drive costs higher. New York, Insurance Information Institute. URL: https://www.iii.org/white-paper/personal-automobile-insurance-more-accidents$\underline{\text { larger-claims-drive-costs-higher-101716 }}$

2. Albright, J., A. Bell, J. Schneider, and C. Nyce (2015). Marketplace of change: Automobile insurance in the era of autonomous vehicles. KPMG. URL: https:/home.kpmg.com/content/dam/kpmg/pdf/2016/05/kpmg-automobile-insurancein-era-autonomous.pdf 


\section{Describe and explain cost-plus pricing in a service firm context, specifying cost categories and their influence on pricing}

Cost-plus pricing is focused on costs in the production phase of the manufacture of products and services. It generally ignores the design phase when most costs are set based on the design plan. In a manufacturing context, total product costs are the sum of variable and fixed costs, while the selling price is determined by adding a profit margin to the total product cost. Variable costs include direct material and labor costs related to product manufacture and other non-direct factory overhead costs (e.g., maintenance costs) incurred within the factory. Fixed costs include factory-related administration costs (e.g., plant manager's salary) and period costs incurred outside the factory (e.g., selling, marketing, and financing costs).

Cost-plus pricing assumes customers accept a price set by the firm for its product and services. While market research may have been conducted to gauge customer demand for the features of a product or service, the underlying assumption of cost-plus pricing is all customers within a market segment pay for all features offered by the firm at any cost. In very competitive and volatile markets, these assumptions may not be valid, and firms need to be more careful about how they determine which features are important to customers and at what value. With cost-plus pricing, when customers turn away from a firm's product or service due to better value offered elsewhere, firms have only one approach to managing the declining demand, and that will be to cut product costs, which may be challenging in the short term. Variable costs may include important capabilities (e.g., skilled underwriting staff) that may be lost to the firm and unavailable when demand picks up if across-the-board cost-cutting approaches are undertaken without a strategic approach to pricing and costing.

In the service sector, the components of variable and fixed costs are different from manufacturing; adopting cost-plus pricing in the service environment may prove to be 
problematic in a competitive and volatile market. The largest element of variable costs in a service firm (e.g., auto insurance) typically relates to labor costs. Material and other types of variable costs (e.g., maintenance) are generally a small portion of these. Fixed costs include cost categories that are of a significant magnitude that create lower operating leverage and consequently reduce operating flexibility for service firms. Fixed costs, such as branding and marketing, are a large component of total cost and need to be managed carefully as they reduce the firm's ability to manage costs in the short-term. Adopting cost-plus pricing approaches in a competitive service market creates inflexible cost-management challenges for firms. Even for technology-related manufactured products (e.g., smart phones), fixed costs related to branding and marketing are a huge impost and create lower operating leverage, which requires careful management in a highly competitive market. A more strategic approach to pricing and costing, such as TC, might need to be considered by the service firm.

\section{Explain the key steps involved in TC.}

TC is a strategic approach to cost management that commences from "outside-in" by examining customer needs, desired features, and the price they are willing to pay, and then working out an allowable cost for the product or service that should be incurred in designing and producing it. TC focuses on both the design and production phases of the manufacture of products and services. In most firms in the design phase, costs are built into the product or service that cannot be undone later by cutting costs in the production phase of manufacturing.

TC takes a strategic and lifecycle approach to cost management. TC focuses on costs within the firm and along its value chain. In many firms, product costs are incurred outside the firm by supply partners along the value chain. A TC approach encourages collaboration between the firm and its supply partners in strategically managing the costs of the product or service. In order to use TC, a firm should 
- strategically manage future profitability of a product;

- consider cost as an input to the product development process, not an outcome;

- understand customer functionality and quality requirements;

- understand the price customers will pay;

- understand the profit margin required; and

- calculate the product cost as the selling price minus the profit margin.

In summary, Target Cost $=$ Selling Price - Profit Margin .

The TC process is illustrated in figure 1.

\section{[INSERT FIGURE 1 HERE]}

Costs are considered at two levels. First, costs are considered at the market level by examining what features the customer requires and will pay for-this provides an overall product-level TC. This product-level TC, also referred to as the allowable cost, will usually be lower than the current product costs incurred by the firm. Next, the firm will decompose this TC into component-level costs to establish a TC for each component of the product. This component-level TC will normally be lower than the component-level costs incurred by the firm's partners in supplying components. Once the allowable costs are determined, the firm enters a cost-management process that focuses on the design and production phases of the product and examines ways to reduce current costs to the allowable costs. This process includes cost-cutting initiatives; however, the difference now is the cost cutting is done in a strategic way to ensure the firm is able to meet its strategic objectives without cutting out key competencies or related infrastructure within the firm. The cost-management process may reduce current costs to the allowable cost over a defined period, with strategic cost-reduction targets being established to guide the process. The full process of TC is illustrated in figure 2 . 
[INSERT FIGURE 2 HERE]

\section{Assess the specific challenges of introducing TC in a service firm as opposed to a manufacturing firm. How should TC be adapted in a service firm?}

Service firms are different from manufacturing firms in several ways:

- They may produce intangible and in some cases perishable "products" (e.g., consulting hours).

- There may be no significant design and production phases.

- The main product costs relate to labor costs.

- The relevant range or capacity is not a major issue.

- Fixed costs (e.g., branding and marketing) are a large percentage of total product costs.

Engaging with customers to ascertain valuable "product features" can be a challenge for an intangible service. The service offering (e.g., Ride Cover) and its key features need to be clearly specified to determine which features are valuable to customers before a selling price can be developed.

The allowable cost is determined by taking away the expected profit margin from the target selling price. A large portion of the allowable cost is labor costs in a service firm; how these costs are managed and reduced is challenging. The increased use of technology to automate business processes (e.g., claims) can be one option to explore.

Branding and marketing costs can be another huge impost in service firms. As firms develop innovative ways to design distribution channels and develop new service offerings, promoting their brand becomes an important factor. Improving the effectiveness of this cost can be a challenge. 
Cost management has a long history in manufacturing firms, where the lead times and investment in capital infrastructure can be significant and require long-term cost planning and management. Managerial accounting began as cost accounting in manufacturing firms and still retains terminology from these origins. The use of cost-management practices in the service sector is a new phenomenon, and getting management buy-in and operational capability can be a challenge. When traditional costing practices (e.g., cost-plus pricing) are used in a limited manner, gaining traction on strategic cost management approaches (e.g., TC) can be challenging but worth pursuing.

\section{How would you improve the profitability of Sunline?}

It is likely this question will encourage the most debate and discussion in class around the different strategies that can be applied to reduce costs, thereby achieving the target cost while still delivering the competitive advantage of Sunline's Ride Cover policy. We provide some examples for consideration in this section, but it is expected students will have a range of ideas to achieve the target cost. The associated spreadsheet, available with this case, includes the information and associated calculations from Table 2 (provided in the case) and an 'alternative scenario', based on the suggestion below and illustrated in Table 1 (below), to reduce costs to the target cost level. We recommend distributing only the "Quarter 4 costs" (table 2 provided in the case) worksheet to students so they can modify the numbers in line with their suggestions and then subsequently refer to the "alternative scenario" worksheet or table 1 as the basis of class discussion. The rows highlighted in grey indicate the changes that have been made in the alternative scenario worksheet and Table 1. Note: The leftmost cell (worksheet) or number (Table 1) that is highlighted relates to the one where the change is driving the overall cost change for each row (e.g., average unit cost, unit number, or the total amount). 
[INSERT TABLE 1 HERE]

Table 4 (provided in the case) identifies the magnitude of cost cutting (28 percent) required using a TC approach. According to Table 2 (provided in the case), payroll costs represent 45 percent of total costs and are clearly the area to focus on. In service firms like personal auto insurance, payroll or labor costs are normally the largest cost item. Unlike traditional manufacturing (e.g., automotive), where material costs can be as high as labor costs, in service firms material costs are negligible while labor costs can be a major portion of total costs.

Personal auto insurance's business model focuses on two key areas: underwriting new policies (i.e., product sales) and managing claims. Given the target of 20 new policy sales per week, underwriting staff appear to be underperforming considerably. This suggests a tighter degree of control may be required over underwriters to increase their performance. This may also facilitate a reduction in this cost area, as the number of sales staff could be reduced if each was higher performing. The alternative scenario illustrates a reduction in the number of sales staff and a higher commission to motivate the remaining staff to perform better. It could also be considered that improvement in Sunline's website, illustrated by further expenditure on the website in the alternative scenario, could also cut purchases at the store level, which would allow a reduction in the underwriters required and expenditures related to Sunline store locations. The integration of operations and associated costs (e.g., salaries, technology, and leasing) can be discussed and is important in devising a strategy to reach the target cost.

Claims management is a labor-intensive process and involves specialist staff to investigate and resolve claims made by customers on insurance policies. Key activities related to personal auto claims include receipt of claims, desk investigation of claimants' cases, external investigation of claimants' cases using outside investigators, payment or refusal of 
claims, customer service and support of claimant, and accounting for claims and claim payments, including claims reserving. Sunline Auto's claim processes may be labor intensive and carried out by claims teams based in Los Angeles, where labor costs can be high. Claims processes themselves can be primarily manual, not very streamlined, and may be costlier than they need to be. The use of technology to streamline claims processes and to enable "straightthrough processing" of claims could help reduce claims-management costs and, in particular, associated labor costs. Straight-through processing of claims involves claims that are of a standard nature (as defined by Sunline) that can be lodged, investigated, and either paid or refused with limited human processing, with all paperwork lodged electronically. Only complex claims involving human judgment and decisions are handled by experienced claims staff. As illustrated in our alternative scenario, improving the technology (software/information systems subscriptions) and reducing the staffing cost may contribute considerably to achieving the target cost.

Students can be asked to prepare cost estimates for changes in administration costs resulting from changes in business processes. For example, students can be asked to calculate new underwriting costs if revenue rises by 10 or 20 percent. Costs can be estimated by using current labor costs to revenue ratios and headcount. Students can be asked to estimate claimsprocess costs by developing a scenario where technology replaces manual claims processing. Assume technology can reduce the claims processing staff headcount by 50 percent and rework costs. Alternate scenarios for headcount reduction (e.g., 20 percent, 30 percent) can be used to develop alternate cost estimates.

Another area of high cost in a service firm relates to sales and marketing (according to Table 2 provided in the case, 17 percent of existing total costs). Sunline Auto adopted new distribution channels for getting its service to customers and is making use of social media and 
other platforms to promote its brand and service. It might be worth investigating how effective these channels are for promoting the brand and services and if there are opportunities to reduce the costs by adopting other promotional channels. Instructors should encourage students to think about possible options for alternative promotional channels or reprioritizing marketing expenditure such that it yields greater returns. For example, attending and promoting the brand and services at automotive events as opposed to TV and billboard advertising, illustrated in the alternative scenario.

One large cost of operations is retail leases. It can be argued that leasing locations outside large shopping malls, and the improvement in Sunline's webpage, negates the need for highcost shopping mall leases. While further investigation is required, it could be the case that customers are indifferent about store locations or may find it more convenient to quickly access store locations on retail strips rather than in large shopping malls. Such a move may significantly reduce the average cost of retail leases as shown in the alternative scenario.

Another high cost area according to Table 2, provided in the case, appears to be claims costs at 11 percent. This cost mainly represents costs of claims not included in "prior reserving." Similar to creating provisions for bad and doubtful debts, insurance firms create reserves from profits to cover future claims. Reserving is based on past claims history, future profit and claims forecasts, and reserving policies of competitors. The high cost of claims could represent poor reserving practices, higher-than-expected claims due to unforeseen events, or increased provisioning to cover expected downturns in the economy. An investigation of this high claims costs would be useful to identify potential future cost savings. It is important to consider that the owner's choice of repairer may increase these costs; however, this is an important part of Ride Cover's unique product offering and competitive advantage. 
Based on the above suggestions, the alternative scenario illustrates a reduction in cost below the target cost. The probability of achieving the target cost and whether the competitive advantage of Sunline and the Ride Cover policy can be maintained with this cost restructuring needs to be considered.

\section{Evaluate and explain the key challenges (cultural, management systems, information needs, etc.) involved in implementing a TC approach at Sunline.}

Strategic cost-management approaches such as TC require a "whole of firm" approach to succeed. TC cannot be implemented piecemeal, in uncoordinated strategic moves and without buy-in from all staff within the firm and in partner firms within the value chain. TC cannot be implemented overnight and may take a period of time to be successful. TC is not the responsibility of the senior management team or the accounting function alone; $\mathrm{TC}$ requires an interdisciplinary and inter-functional team-based approach. TC is everyone's business if it is to succeed.

TC must start with the firm's strategic management processes. The firm must determine how it will strategically manage its product and service costs and develop a strategic plan that reflects the TC approach. The firm needs to clearly develop its understanding of who its customers are, of the value propositions it wishes to offer these customers (competitive advantage), and which design products and services will enable these value propositions to be delivered.

A good understanding of the features of products and services expected by customers will help the firm determine the selling price. This process requires the firm to do more than carry out a broad-based focus group assessment of customer preferences and willingness to pay. Each key feature of the product or service must be assessed with a representative group of customers and be compared to similar features in competitor products, and a pricing range 
should be chosen from which a final target selling price can be established. An ongoing refinement process will eventually provide an acceptable selling price.

The firm also needs to be clear on the target return it requires over a period of three to five years based on its capital requirements and be able to translate this margin down to a product and service level. While this sounds like a simple task, in many firms this process will be a challenge. Many firms do not have a clear expectation of financial returns and tend to operate opportunistically, taking whatever level of return they can extract from their operations. Once this return is determined, the firm can arrive at an allowable cost by taking this margin away from the targeted selling price.

Delivering on the allowable cost will require the firm to establish effective and efficient management and operational processes and transform its culture to support TC. Firms such as Toyota spend years investing in process improvement initiatives, using techniques such as Lean and Six Sigma to scientifically assess the efficiency and effectiveness of all activities to improve processes to operate at cost levels that support the firm's target costs for products. The firm's culture needs to encourage and embrace activities where each employee is committed to thinking about and acting on cost improvements. Timely and accurate accounting information on costs needs to be available to signal to all staff areas where costs need to be reduced.

Adopting a TC approach requires a firm to align its strategy with its business model, to initiate improved management and operational processes that transform its culture, and to collect information to enable staff to focus on cost management that is strategic and long-term. The firm needs to clearly define its business model, its value propositions, customer relationships and segments, and tailor products and services to each segment. Customer intimacy — knowing well each type of customer's needs, expectations, and budget—-becomes important to assess what features of the product or service they require and how much they are 
willing to pay. Equally important are the value chain partnerships and an intimate understanding of the business model of key partners to ensure they are willing and able to strategically manage the component costs that feed into the focal firm's service costs. 


\section{REFERENCES}

Albright, J., A. Bell, J. Schneider and C. Nyce. (2015). "Marketplace of change: Automobile insurance in the era of autonomous vehicles." $\underline{\text { KPMG}}$, from https://home.kpmg.com/us/en/home/insights/2016/05/era-of-autonomous-vehiclessurvey.html.

Bolt-Lee, C. and S. Foster (2003). The core competency framework: A new element in the continuing call for accounting education change in the United States. Accounting Education: An International Journal 12 (1): 33-47.

Cooper, R. and R. Slagmulder (1999). Develop profitable new products with target costing. MIT Sloan Management Review 40 (4): 23-33.

Everaert, P., S. Loosveld, T. Van_Acker, M. Schollier and G. Sarens (2006). Characteristics of target costing: theoretical and field study perspectives. Qualitative Research in Accounting and Management 3 (3): 236-263.

Everaert, P. and D. W. Swenson (2014). Truck redesign case: Simulating the target costing process in a product design environment. Issues in Accounting Education 29 (1): 6185.

Gazzaway, T., G. Kim, K. Malinconico and L. Newport (2010). The evolving accounting talent profile: CFO strategies for attracting, training and retaining accounting professionals. Public Policy and External Affairs, Grant Thornton.

Hartwig, R. P., J. Lynch and S. Welsbart. (2016). "Personal automobile insurance: More accidents, larger claims drive costs higher." Insurance Information Institute, from https://www.iii.org/white-paper/personal-automobile-insurance-more-accidentslarger-claims-drive-costs-higher-101716. 
Holtzman, Y. (2004). The transformation of the accounting profession in the United States: From information processing to strategic business advising. Journal of Management Development 23 (10): 949-961.

Mansury, M. A. and J. H. Love (2008). Innovation, productivity and growth in US business services: A firm-level analysis. Technovation 28 (1): 52-62. 


\section{APPENDICES: CASE LEARNING OBJECTIVES AND IMPLEMENTATION GUIDANCE}

\section{Appendix 1: Teaching plan for lecture and tutorial format}

\begin{tabular}{|c|c|c|c|}
\hline Item & Activity & Description & Suggested time \\
\hline \multicolumn{4}{|c|}{ Pre-work (prior to lecture) } \\
\hline 1 & Readings prior to lecture & $\begin{array}{l}\text { 1. Cooper, R., and R. Slagmulder (1999). Develop profitable new products with } \\
\text { target costing. MIT Sloan Management Review } 40 \text { (4): } 23 \\
\text { 2. Everaert, P., and D. W. Swenson (2014). Truck redesign case: Simulating the } \\
\text { target costing process in a product design environment. Issues in Accounting } \\
\text { Education 29 (1): } 110-128 \text {. } \\
\text { 3. Hartwig, R. P., J. Lynch, and S. Welsbart (2016). Personal automobile } \\
\text { insurance: More accidents, larger claims drive costs higher. New York, } \\
\text { Insurance Information Institute. } \\
\text { 4. Albright, J., A. Bell, J. Schneider, and C. Nyce (2015). Marketplace of change: } \\
\text { Automobile insurance in the era of autonomous vehicles, KPMG. } \\
\text { 5. Sunline Auto Insurance case }\end{array}$ & 2.5 hours \\
\hline \multicolumn{4}{|c|}{$\begin{array}{l}\text { In lecture: } \\
\text { Undergraduate: } 1.5 \text { hours allocated } \\
\text { Graduate: } 1 \text { hour allocated }\end{array}$} \\
\hline 2 & $\begin{array}{l}\text { Lecture on strategic cost } \\
\text { management }\end{array}$ & $\begin{array}{l}\text { 1. Lecture on strategic cost management practice delivered, including target } \\
\text { costing. } \\
\text { 2. Students reminded they are to complete the Sunline Auto Insurance case } \\
\text { readings and associated questions. }\end{array}$ & $1-1.5$ hours \\
\hline \multicolumn{4}{|c|}{ Pre-work (prior to tutorial) } \\
\hline 3 & $\begin{array}{l}\text { Homework prior to } \\
\text { tutorial }\end{array}$ & $\begin{array}{l}\text { 1. Students to complete case questions } 1-6 \text {. } \\
\text { 2. Remind students they should participate in the tutorial by sharing their answers } \\
\text { where relevant. }\end{array}$ & 2 hours \\
\hline
\end{tabular}




\section{Appendix 1: Teaching plan for lecture and tutorial format (continued)}

\begin{tabular}{|c|c|c|c|}
\hline Item & Activity & Description & Suggested time \\
\hline \multicolumn{4}{|c|}{$\begin{array}{l}\text { In tutorial } \\
\text { Undergraduate: } 1.5 \text { hours allocated } \\
\text { Graduate: } 2 \text { hours allocated }\end{array}$} \\
\hline 4 & Introduction & $\begin{array}{l}\text { Review of strategic cost management and relevance of Sunline Auto Insurance in this } \\
\text { context. }\end{array}$ & $\begin{array}{l}\text { Undergraduate: } 10 \text { minutes } \\
\text { Graduate: } 15 \text { minutes }\end{array}$ \\
\hline 5 & Case facilitation (part 1) & $\begin{array}{l}\text { Undergraduate: Assigned group to present an overview of the case and present answers } \\
\text { to case questions 1-4 (below). Group to provide opportunities for class participation } \\
\text { while delivering presentation. This is to be facilitated by the instructor where required. } \\
\text { Graduate: Instructor to require class participation through facilitating students' answers } \\
\text { to case questions } 1-4 \text { (below). } \\
\text { Case questions: } \\
\text { 1. Describe the general competitive environment of the auto insurance industry. } \\
\text { 2. Describe and discuss cost-plus pricing in a service business context, specifying cost } \\
\text { categories and their influence on pricing. } \\
\text { 3. Describe and discuss the key steps involved in TC. Use table } 4 \text { as the basis for your } \\
\text { discussion. } \\
\text { 4. Discuss the specific challenges of introducing TC in a service firm as opposed to a } \\
\text { manufacturing firm. How should TC be adapted in a service firm? }\end{array}$ & $\begin{array}{l}\text { Undergraduate: } 25 \text { minutes } \\
\text { Graduate: } 35 \text { minutes }\end{array}$ \\
\hline
\end{tabular}




\section{Appendix 1: Teaching plan for lecture and tutorial format (continued)}

\begin{tabular}{|c|c|c|c|}
\hline Item & Activity & Description & Suggested time \\
\hline 6 & Case facilitation (part 2) & $\begin{array}{l}\text { Undergraduate: Assigned group to address case questions 5-6 (below). This part of the } \\
\text { presentation is to involve active class participation, enabling students to share their } \\
\text { views, opinions, and ideas related to these questions. The instructor will need to } \\
\text { actively facilitate this part of the class to ensure students are provided with the } \\
\text { opportunity to engage in class discussion. } \\
\text { Graduate: Instructor to facilitate class discussion relating to case questions 5-6 (below) } \\
\text { to ensure students are provided with the opportunity to share a variety of views, } \\
\text { opinions and ideas. } \\
\text { Case questions: } \\
5 . \text { How would you improve the profitability of Sunline? List and discuss specific steps } \\
\text { you would consider. Focus on the costs currently incurred and how they could be } \\
\text { reprioritized and cut to meet the target cost, in line with the current competitive } \\
\text { positioning. Use the information in tables } 2-4 \text { to illustrate and justify your answer. } \\
6 . \text { Identify and discuss the key challenges (cultural, management systems, information } \\
\text { needs, etc.) involved in implementing a TC approach at Sunline. }\end{array}$ & $\begin{array}{l}\text { Undergraduate: } 30 \text { minutes } \\
\text { Graduate: } 45 \text { minutes }\end{array}$ \\
\hline 7 & Final class discussion & $\begin{array}{l}\text { Facilitate class discussion focusing on the value relevance of using target costing in the } \\
\text { service sector. }\end{array}$ & 15 minutes \\
\hline
\end{tabular}




\section{Appendix 2: Teaching plan for three-hour seminar format class}

\begin{tabular}{|c|c|c|c|}
\hline Item & Activity & Description & Suggested time \\
\hline \multicolumn{4}{|c|}{ Pre-work (prior to class) } \\
\hline 1 & Readings prior to class & $\begin{array}{l}\text { 1. Cooper, R., and R. Slagmulder (1999). Develop profitable new products with } \\
\text { target costing. MIT Sloan Management Review } 40 \text { (4): 23-33 } \\
\text { 2. Everaert, P., and D. W. Swenson (2014). Truck redesign case: Simulating the } \\
\text { target costing process in a product design environment. Issues in Accounting } \\
\text { Education } 29 \text { (1): 110-128. } \\
\text { 3. Hartwig, R. P., J. Lynch, and S. Welsbart (2016). Personal automobile } \\
\text { insurance: More accidents, larger claims drive costs higher. New York, } \\
\text { Insurance Information Institute. } \\
\text { 4. Albright, J., A. Bell, J. Schneider, and C. Nyce (2015). Marketplace of change: } \\
\text { Automobile insurance in the era of autonomous vehicles, KPMG. } \\
\text { 5. Sunline Auto Insurance }\end{array}$ & 2.5 hours \\
\hline 2 & $\begin{array}{l}\text { Homework: six case } \\
\text { questions }\end{array}$ & $\begin{array}{l}\text { 1. Students to complete case questions } \\
\text { 2. Remind students they should be ready to discuss the case and their answers in } \\
\text { class }\end{array}$ & 2 hours \\
\hline \multicolumn{4}{|c|}{ ( } \\
\hline 3 & $\begin{array}{l}\text { Initial overview of case } \\
\text { in class }\end{array}$ & $\begin{array}{l}\text { Generate class discussion to initially remind students of the case through asking the } \\
\text { following questions: } \\
\text { 1. What challenges does Sunline face? } \\
\text { 2. Describe the financial performance of Sunline. } \\
\text { 3. Discuss the competitive positioning of Sunline. }\end{array}$ & 20 minutes \\
\hline 4 & $\begin{array}{l}\text { Facilitate class } \\
\text { discussion of auto } \\
\text { insurance industry }\end{array}$ & $\begin{array}{l}\text { Relate discussion to homework question: } \\
\text { 1. Describe the general competitive environment of the auto insurance industry. } \\
\text { Link discussion to the competitive positioning of Sunline }\end{array}$ & 15 minutes \\
\hline
\end{tabular}


Appendix 2: Teaching plan for three-hour seminar format class (continued)

\begin{tabular}{|c|c|c|c|}
\hline Item & Activity & Description & Suggested time \\
\hline 5 & $\begin{array}{l}\text { Compare cost-plus } \\
\text { pricing and target costing }\end{array}$ & $\begin{array}{l}\text { Relate discussion to homework questions: } \\
\text { 2. Describe and discuss cost-plus pricing in a service business context, specifying cost } \\
\text { categories and their influence on pricing. } \\
\text { 3. Describe and discuss the key steps involved in TC. Use table } 4 \text { as the basis for your } \\
\text { discussion. }\end{array}$ & 20 minutes \\
\hline 6 & $\begin{array}{l}\text { Discuss how target } \\
\text { costing can be adapted to } \\
\text { the service context }\end{array}$ & $\begin{array}{l}\text { Relate discussion to homework question: } \\
\text { 4. Discuss the specific challenges of introducing TC in a service firm as opposed to a } \\
\text { manufacturing firm. How should TC be adapted in a service firm? }\end{array}$ & 15 minutes \\
\hline 7 & $\begin{array}{l}\text { Small group breakout } \\
\text { session to discuss how } \\
\text { Sunline costs can be cut } \\
\text { using the target cost }\end{array}$ & $\begin{array}{l}\text { Ask students to form groups of three and compare and discuss how they would reduce } \\
\text { costs to the target level while maintaining Sunline's strategic positioning. } \\
\text { Ask each group of students to agree on a shared perspective on how they will achieve } \\
\text { the target cost and be ready to present this to the class. } \\
\text { As part of this discussion students should consider their answer to the homework } \\
\text { question: } \\
5 . \text { How would you improve the profitability of Sunline? List and discuss specific steps } \\
\text { you would consider. Focus on the costs currently incurred and how they could be } \\
\text { reprioritized and cut to meet the target cost, in line with the current competitive } \\
\text { positioning. Use the information in tables } 2-4 \text { to illustrate and justify your answer. }\end{array}$ & 25 minutes \\
\hline 8 & $\begin{array}{l}\text { Small group breakout } \\
\text { session to discuss the key } \\
\text { challenges involved in } \\
\text { implementing target } \\
\text { costing }\end{array}$ & $\begin{array}{l}\text { Ask students to work in the same groups of three and discuss their answers to the } \\
\text { homework question and incorporate this perspective into their presentation: } \\
\text { 6. Identify and discuss the key challenges (cultural, management systems, information } \\
\text { needs, etc.) involved in implementing a TC approach at Sunline. }\end{array}$ & 20 minutes \\
\hline 9 & Group presentations & $\begin{array}{l}\text { Groups to present for five minutes, depending on time available and how many groups } \\
\text { in the class. }\end{array}$ & 25 minutes \\
\hline 10 & Final class discussion & $\begin{array}{l}\text { Facilitate class discussion focusing on the value relevance of using target costing in the } \\
\text { service sector. }\end{array}$ & 20 minutes \\
\hline
\end{tabular}




\section{Appendix 3: Teaching plan for online class}

\begin{tabular}{|c|c|c|c|}
\hline Item & Activity & Description & Suggested time \\
\hline \multicolumn{4}{|c|}{ Pre-work (prior to first online class) } \\
\hline 1 & Readings & $\begin{array}{l}\text { 1. Cooper, R., and R. Slagmulder (1999). Develop profitable new products with } \\
\text { target costing. MIT Sloan Management Review } 40 \text { (4): } 23 \\
\text { 2. Everaert, P., and D. W. Swenson (2014). Truck redesign case: Simulating the } \\
\text { target costing process in a product design environment. Issues in Accounting } \\
\text { Education } 29 \text { (1): 110-128. } \\
\text { 3. Hartwig, R. P., J. Lynch, and S. Welsbart (2016). Personal automobile } \\
\text { insurance: More accidents, larger claims drive costs higher. New York, } \\
\text { Insurance Information Institute. } \\
\text { 4. Albright, J., A. Bell, J. Schneider, and C. Nyce (2015). Marketplace of change: } \\
\text { Automobile insurance in the era of autonomous vehicles, KPMG. } \\
\text { 5. Sunline Auto Insurance }\end{array}$ & 2.5 hours \\
\hline 2 & $\begin{array}{l}\text { Homework prior to } \\
\text { online lesson }\end{array}$ & $\begin{array}{l}\text { 1. Students to complete case questions } 1-4 \\
\text { 2. Remind students they should be ready to discuss the cases and their answers in } \\
\text { the lecture }\end{array}$ & 1 hour \\
\hline \multicolumn{4}{|c|}{ First online class (1.5 hours allocated time) } \\
\hline 3 & Initial overview of case & $\begin{array}{l}\text { Provide a general overview of the case, discussing the following (with student input } \\
\text { where practical): } \\
\text { 1. The challenges Sunline faces } \\
\text { 2. The financial performance of Sunline } \\
\text { 3. The competitive positioning of Sunline }\end{array}$ & 20 minutes \\
\hline 4 & $\begin{array}{l}\text { Describe the } \\
\text { characteristics of the auto } \\
\text { insurance industry while } \\
\text { seeking student input. }\end{array}$ & $\begin{array}{l}\text { Relate description to homework question: } \\
\text { 1. Describe the general competitive environment of the auto insurance industry. } \\
\text { Link description to the competitive positioning of Sunline }\end{array}$ & 15 minutes \\
\hline
\end{tabular}




\section{Appendix 3: Teaching plan for online class (continued)}

\begin{tabular}{|c|c|c|c|}
\hline Item & Activity & Description & Suggested time \\
\hline 5 & $\begin{array}{l}\text { Compare cost-plus } \\
\text { pricing and target costing }\end{array}$ & $\begin{array}{l}\text { Relate explanation to homework questions: } \\
\text { 2. Describe and discuss cost-plus pricing in a service business context, specifying cost } \\
\text { categories and their influence on pricing. } \\
\text { 3. Describe and discuss the key steps involved in TC. Use table } 4 \text { as the basis for your } \\
\text { discussion. } \\
\text { Provide opportunities for student input and questions via an online platform. }\end{array}$ & 20 minutes \\
\hline 6 & $\begin{array}{l}\text { Discuss how target } \\
\text { costing can be adapted to } \\
\text { the service context }\end{array}$ & $\begin{array}{l}\text { Relate explanation to homework question: } \\
\text { 4. Discuss the specific challenges of introducing TC in a service firm as opposed to a } \\
\text { manufacturing firm. How should TC be adapted in a service firm? } \\
\text { Provide opportunities for student input and questions via an online platform. }\end{array}$ & 15 minutes \\
\hline \multicolumn{4}{|c|}{ Pre-work (prior to second online class) } \\
\hline 7 & $\begin{array}{l}\text { Homework prior to } \\
\text { second online class }\end{array}$ & $\begin{array}{l}\text { 1. Students to complete case questions } 5-6 \text { and submit detailed answers to online } \\
\text { instructor in advance of second online class. } \\
\text { 2. Remind students they should be ready to comment via online platform based } \\
\text { on detailed homework answers. }\end{array}$ & 1 hour \\
\hline 8 & $\begin{array}{l}\text { Student peer review of } \\
\text { fellow students' } \\
\text { responses }\end{array}$ & $\begin{array}{l}\text { Instructor to assign students to groups of three. Students are provided the responses of } \\
\text { their fellow group members and asked to "critically evaluate and comment on their } \\
\text { fellow students' responses to case questions 5-6 (below)." Students are required to } \\
\text { submit these evaluations and comments to their fellow group members. } \\
\text { 5. How would you improve the profitability of Sunline? List and discuss specific steps } \\
\text { you would consider. Focus on the costs currently incurred and how they could be } \\
\text { reprioritized and cut to meet the target cost, in line with the current competitive } \\
\text { positioning. Use the information in tables } 2-4 \text { to illustrate and justify your answer. } \\
\text { 6. Identify and discuss the key challenges (cultural, management systems, information } \\
\text { needs, etc.) involved in implementing a TC approach at Sunline. }\end{array}$ & 1 hour \\
\hline
\end{tabular}




\section{Appendix 3: Teaching plan for online class (continued)}

\begin{tabular}{|c|c|c|c|}
\hline Item & Activity & Description & Suggested time \\
\hline \multicolumn{4}{|c|}{ Second online class (1.5 hours allocated time) } \\
\hline 9 & Review of case facts & Brief review of case information, based on items 3 and 4 above. & 10 minutes \\
\hline 10 & $\begin{array}{l}\text { Group breakout session } \\
\text { to discuss how Sunline } \\
\text { costs can be cut using the } \\
\text { target cost }\end{array}$ & $\begin{array}{l}\text { Using three-way online communication tool (or phone call), student groups of } 3 \text { asked } \\
\text { to discussed their views on question } 5 \text { responses, they have previously shared and } \\
\text { evaluated as part of item } 8 \text { (above). } \\
\text { Ask each group of students to agree on a shared perspective on how they will achieve } \\
\text { the target cost, while maintaining Sunline's strategic positioning. }\end{array}$ & 30 minutes \\
\hline 11 & $\begin{array}{l}\text { Group breakout session } \\
\text { to discuss the key } \\
\text { challenges involved in } \\
\text { implementing target } \\
\text { costing }\end{array}$ & $\begin{array}{l}\text { Using three-way online communication tool (or phone call) student groups of three } \\
\text { discuss their answers to the homework question } 6 \text {. } \\
\text { Ask each group of students to agree on a shared perspective on the key challenges } \\
\text { involved in implementing target costing. }\end{array}$ & 25 minutes \\
\hline 12 & Final class conclusion & $\begin{array}{l}\text { Instructor to discuss the key points raised for questions } 5 \text { and } 6 \text { (based on the responses } \\
\text { previously submitted for item } 7 \text { above) and the value relevance of using target costing } \\
\text { in the service sector. }\end{array}$ & 15 minutes \\
\hline
\end{tabular}




\section{APPENDIX: TEACHING NOTES}

\section{Appendix 1: Grading Rubric}

\begin{tabular}{|c|c|c|c|}
\hline Marking Component & Exceeds Criteria & Meets Criteria & Criteria not met \\
\hline $\begin{array}{l}\text { Demonstrable knowledge of } \\
\text { product costs }\end{array}$ & $\begin{array}{l}\text { Very good understanding of product costs. } \\
\text { Ability to decompose costs into direct and } \\
\text { indirect costs and to further detail direct costs } \\
\text { into material and labor costs. Able to discuss } \\
\text { strategic importance of direct and indirect costs. }\end{array}$ & $\begin{array}{l}\text { Satisfactory understanding of product costs. Limited } \\
\text { ability to decompose costs into direct and indirect } \\
\text { costs and to further detail direct costs into material } \\
\text { and labor costs. Unable to discuss strategic } \\
\text { importance of direct and indirect costs. }\end{array}$ & $\begin{array}{l}\text { Poor understanding of product costs. Lacks } \\
\text { ability to decompose costs into direct and } \\
\text { indirect costs and to further detail direct costs } \\
\text { into material and labor costs. Not able to } \\
\text { discuss strategic importance of direct and } \\
\text { indirect costs. }\end{array}$ \\
\hline $\begin{array}{l}\text { Understanding of cost-plus } \\
\text { pricing methods }\end{array}$ & $\begin{array}{l}\text { Excellent knowledge of cost-plus pricing with } \\
\text { examples to illustrate the positive and negatives } \\
\text { of this pricing method. }\end{array}$ & $\begin{array}{l}\text { Satisfactory knowledge of cost-plus pricing with } \\
\text { limited examples. Satisfactory illustration of the } \\
\text { positive and negatives of this pricing method. }\end{array}$ & $\begin{array}{l}\text { Poor knowledge of cost-plus pricing and } \\
\text { unable to illustrate the positive and negatives } \\
\text { of this pricing method. }\end{array}$ \\
\hline $\begin{array}{l}\text { Demonstrable knowledge of } \\
\text { target costing principles }\end{array}$ & $\begin{array}{l}\text { Excellent knowledge of target costing } \\
\text { principles. Clear ability to discuss the key steps } \\
\text { in the approach with examples and the } \\
\text { challenges involved in applying the approach. }\end{array}$ & $\begin{array}{l}\text { Satisfactory knowledge of target costing principles. } \\
\text { Some ability to discuss the key steps in the } \\
\text { approach with examples and the challenges } \\
\text { involved in applying the approach. }\end{array}$ & $\begin{array}{l}\text { Poor knowledge of target costing principles. } \\
\text { Unable to discuss the key steps in the } \\
\text { approach with examples and the challenges } \\
\text { involved in applying the approach. }\end{array}$ \\
\hline $\begin{array}{l}\text { Demonstrable knowledge of } \\
\text { strategic cost management } \\
\text { methods required to reduce } \\
\text { costs }\end{array}$ & $\begin{array}{l}\text { Very good understanding of strategic cost } \\
\text { management approaches to reduce costs. Clear } \\
\text { examples }(2-3) \text { used to illustrate approach. }\end{array}$ & $\begin{array}{l}\text { Satisfactory understanding of strategic cost } \\
\text { management approaches to reduce costs. Some } \\
\text { examples (1-2) used to illustrate approach. }\end{array}$ & $\begin{array}{l}\text { Poor understanding of strategic cost } \\
\text { management approaches to reduce costs. No } \\
\text { examples used to illustrate approach. }\end{array}$ \\
\hline $\begin{array}{l}\text { Critical analysis and } \\
\text { presentation of case }\end{array}$ & $\begin{array}{l}\text { Very good, critical analysis of key issues. Case } \\
\text { write-up is focused, structured, and addresses all } \\
\text { requirements. }\end{array}$ & $\begin{array}{l}\text { Satisfactory analysis of key issues but critical } \\
\text { analysis is limited. Case writeup is satisfactory, with } \\
\text { limited grammatical errors }(2-3) \text {. }\end{array}$ & $\begin{array}{l}\text { Poor analysis of key issues. Case writeup has } \\
\text { been unstructured and poorly done, with } \\
\text { multiple grammatical errors. }\end{array}$ \\
\hline
\end{tabular}




\section{FIGURES: TEACHING NOTES}

Figure 1: The target costing process

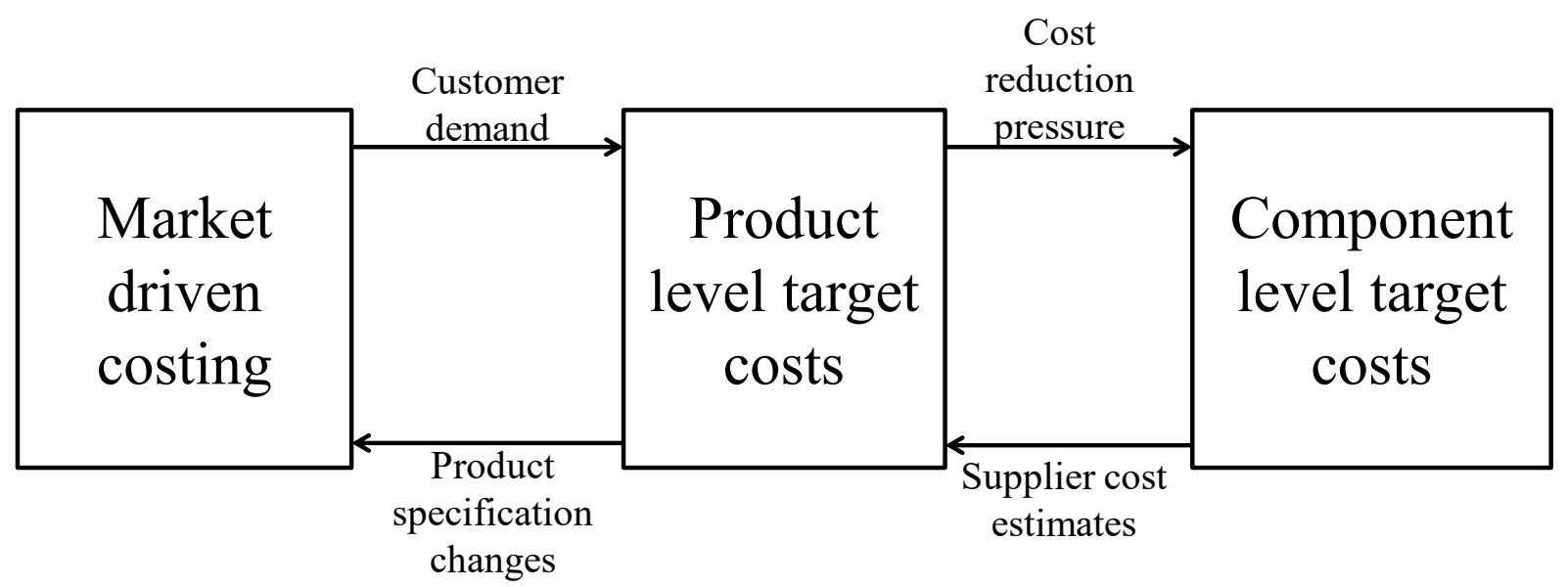


Figure 2: Full target costing process

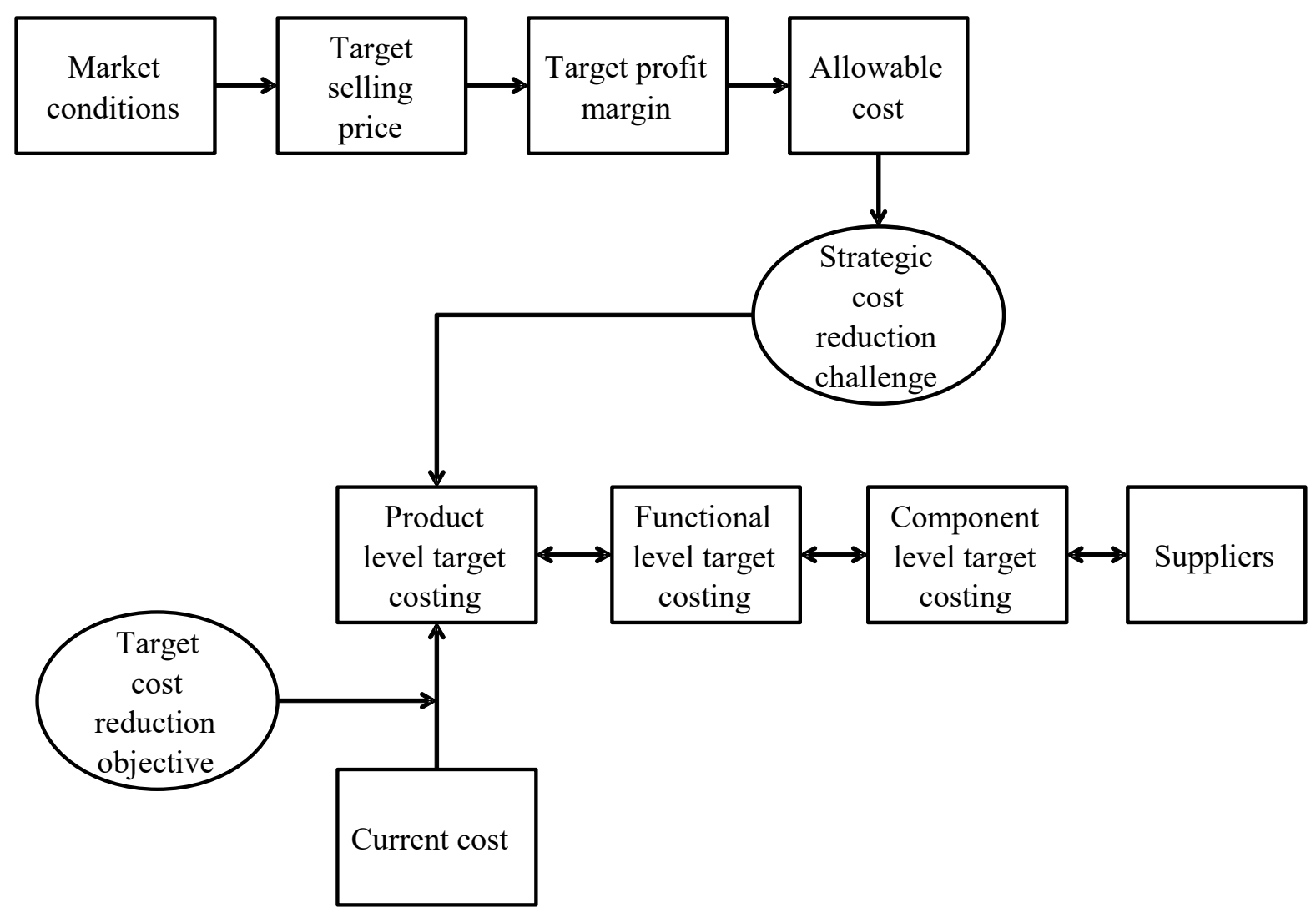


TABLES: "THE CASE" AND "CASE LEARNING OBJECTIVES AND

IMPLEMENTATION GUIDANCE"

Table 1: Sunline quarterly performance summary

\begin{tabular}{lllll}
\hline & Quarter 1 & Quarter 2 & Quarter 3 & Quarter 4 \\
& $\$ \mathrm{M}$ & $\$ \mathrm{M}$ & $\$ \mathrm{M}$ & $\$ \mathrm{M}$ \\
\hline Revenue & 5.43 & 6.01 & 6.50 & 6.91 \\
Cost & 6.41 & 7.30 & 8.01 & 8.69 \\
Profit/(Loss) & $(0.98)$ & $(1.29)$ & $(1.51)$ & $(1.79)$ \\
\hline
\end{tabular}


Table 2: Sunline costs (Quarter 4)

\begin{tabular}{|c|c|c|c|c|}
\hline Cost item & $\begin{array}{l}\text { Cost per unit } \\
\text { (average \$) }\end{array}$ & $\begin{array}{l}\text { No. of } \\
\text { units }\end{array}$ & $\begin{array}{l}\text { Total } \\
(\$)\end{array}$ & $\begin{array}{l}\text { Percentage } \\
(\%)\end{array}$ \\
\hline \multicolumn{5}{|l|}{ Salaries \& wages: } \\
\hline Underwriting salaries (FT salary including on-costs) & 57,963 & 23 & $1,333,149$ & 15.3 \\
\hline $\begin{array}{l}\text { Underwriting commission per policy ( } 10 \% \text { of annual } \\
\text { premium) }\end{array}$ & 120 & 1,250 & 150,000 & 1.7 \\
\hline $\begin{array}{l}\text { Claims and administration staff (FT salary including } \\
\text { on costs) }\end{array}$ & 51,843 & 27 & $1,399,761$ & 16.1 \\
\hline $\begin{array}{l}\text { Management salaries and bonuses (FT salary } \\
\text { including on costs) }\end{array}$ & 125,250 & 5 & 626,250 & 7.2 \\
\hline $\begin{array}{l}\text { Marketing staff salaries (FT salary including on } \\
\text { costs) }\end{array}$ & 75,698 & 5 & 378,490 & 4.4 \\
\hline \multicolumn{5}{|l|}{ Training: } \\
\hline Underwriting training program for new staff & 4,750 & 2 & 9,500 & 0.1 \\
\hline Claims management program for new staff & 3,250 & 2 & 6,500 & 0.1 \\
\hline \multicolumn{5}{|l|}{ Marketing: } \\
\hline TV (cost per campaign) & 179,742 & 3 & 539,226 & 6.2 \\
\hline Billboards & 15,121 & 55 & 831,655 & 9.6 \\
\hline Online advertising including social media & & & 34,564 & 0.4 \\
\hline Event representations (trade stall and setup cost) & 8,700 & 5 & 43,852 & 0.5 \\
\hline \multicolumn{5}{|l|}{ Technology: } \\
\hline Software/information systems subscriptions & & & 23,794 & 0.3 \\
\hline Webpage setup and maintenance & & & 7,662 & 0.1 \\
\hline \multicolumn{5}{|l|}{ Leasing: } \\
\hline $\begin{array}{l}\text { Computer leases (across all Sunline insurance } \\
\text { operations) }\end{array}$ & & & 43,150 & 0.5 \\
\hline Retail store leases & 98,541 & 16 & $1,576,656$ & 18.1 \\
\hline Sunline main office lease & & & 72,500 & 0.8 \\
\hline \multicolumn{5}{|l|}{ Insurance costs: } \\
\hline Claims & & & 932,432 & 10.7 \\
\hline Roadside assistance callout charge & 250 & 1,611 & 402,750 & 4.6 \\
\hline Headquarter charge back & & & 306,467 & 3.5 \\
\hline $\begin{array}{l}\text { Interest earnings on cash provision for insurance } \\
\text { claims }\end{array}$ & & & $(25,000)$ & $(0.3)$ \\
\hline Total costs & & & $8,693,358$ & 100.0 \\
\hline
\end{tabular}


Table 3: Ride Cover policy - Cost-plus pricing (based on Quarter 4)

\begin{tabular}{ll}
\hline Number of policies (end of Quarter 4) & 23,013 \\
Average policy cost & $\$ 377.59$ \\
Target average profit margin & $10 \%$ \\
Cost-plus price & $\$ 415.36$ \\
& \\
Average premium charged (market price) & $\$ 300.00$ \\
Profit/(Loss) per policy & $\$(77.59)$ \\
\hline
\end{tabular}

Note: Policies are more commonly sold on an annual basis. However, for consistency with the cost data in table 2, all data in this table is based on the quarter.

Table 4: Ride Cover - Target costing (based on Quarter 4)

\begin{tabular}{ll}
\hline $\begin{array}{l}\text { Average quarterly sales volume (no. of policies) } \\
\text { Average premium charged (market price) }\end{array}$ & 23,023 \\
& $\$ 300.00$ \\
Target average profit margin & $10 \%$ \\
Target profit margin & $\$ 30.00$ \\
Allowable cost & $\$ 270.00$ \\
Current cost & $\$ 377.59$ \\
Cost savings required & $\$ 107.59$ \\
Cost savings required & $28.49 \%$ \\
\hline
\end{tabular}

Note: Policies are more commonly sold on an annual basis. However, for consistency with the cost data in Table 2, all data in this table is based on the quarter 
Table 5: Case questions mapped to objectives

\begin{tabular}{lll}
\hline No. & Question & Objective \\
\hline 1 & Describe the general competitive environment of the auto insurance industry. & 1 \\
\cline { 2 - 3 } 2 & $\begin{array}{l}\text { Describe and explain cost-plus pricing in a service firm context, specifying cost } \\
\text { categories and their influence on pricing. }\end{array}$ & 2 \\
\cline { 2 - 2 } 3 & $\begin{array}{l}\text { Explain the key steps involved in target costing (TC). Use table 4 as the basis } \\
\text { for your discussion. }\end{array}$ & 2 \\
\cline { 2 - 3 } 4 & $\begin{array}{l}\text { Assess the specific challenges of introducing TC in a service firm as opposed } \\
\text { to a manufacturing firm. How should TC be adapted in a service firm? }\end{array}$ & 2,3 \\
\cline { 2 - 3 } 5 & $\begin{array}{l}\text { How would you improve the profitability of Sunline? Evaluate specific steps } \\
\text { you would consider. Focus on the costs currently incurred and how they could }\end{array}$ & $1,2,3$ \\
& $\begin{array}{l}\text { be reprioritized and cut to meet the target cost, in line with the current } \\
\text { competitive positioning. Use the information in tables 2-4 to illustrate and }\end{array}$ & \\
& $\begin{array}{l}\text { justify your answer. } \\
6\end{array}$ & $\begin{array}{l}\text { Evaluate and explain the key challenges (cultural, management systems, } \\
\text { information needs, etc.) involved in implementing a TC approach at Sunline. }\end{array}$ \\
\hline
\end{tabular}


TABLE 6

Pre- and post-case completion data (Undergraduate, $n=152$ )

\begin{tabular}{|c|c|c|c|c|c|c|c|c|}
\hline Item & Question & $\begin{array}{l}\text { Strongly } \\
\text { disagree } \\
\text { (1) }\end{array}$ & $\begin{array}{l}\text { Disagree } \\
(2)\end{array}$ & $\begin{array}{l}\text { Neutral } \\
(3)\end{array}$ & $\begin{array}{l}\text { Agree } \\
(4)\end{array}$ & $\begin{array}{l}\text { Strongly } \\
\text { agree } \\
(5)\end{array}$ & Mean & $\begin{array}{l}\text { T-test } \\
(t \text {-stat })\end{array}$ \\
\hline $1 \mathrm{a}$ & I can recognize the important areas of cost in a service firm (pre-case) & $0.7 \%$ & $2.0 \%$ & $15.9 \%$ & $61.6 \%$ & $19.9 \%$ & 3.98 & $2.988 * * *$ \\
\hline $1 b$ & I can recognize the important areas of cost in a service firm (post-case) & $0.0 \%$ & $0.0 \%$ & $8.8 \%$ & $68.9 \%$ & $22.3 \%$ & 4.14 & \\
\hline $2 \mathrm{a}$ & I understand the purpose of target costing (pre-case) & $0.0 \%$ & $0.7 \%$ & $13.9 \%$ & $59.6 \%$ & $25.8 \%$ & 4.11 & $4.832 * * *$ \\
\hline $2 b$ & I understand the purpose of target costing (post-case) & $0.0 \%$ & $0.0 \%$ & $5.4 \%$ & $57.1 \%$ & $37.4 \%$ & 4.32 & \\
\hline $3 a$ & I can apply target costing to a service firm (pre-case) & $0.0 \%$ & $4.6 \%$ & $37.7 \%$ & $44.4 \%$ & $13.2 \%$ & 3.66 & $3.652 * * *$ \\
\hline $3 b$ & I can apply target costing to a service firm (post-case) & $0.0 \%$ & $2.0 \%$ & $23.1 \%$ & $60.5 \%$ & $14.3 \%$ & 3.87 & \\
\hline $4 a$ & $\begin{array}{l}\text { I can creatively consider service firm costs in the context of competitive } \\
\text { positioning and competitive advantage (pre-case) }\end{array}$ & $0.0 \%$ & $3.3 \%$ & $42.4 \%$ & $45.0 \%$ & $9.3 \%$ & 3.60 & $3.309 * * *$ \\
\hline $4 b$ & $\begin{array}{l}\text { I can creatively consider service firm costs in the context of competitive } \\
\text { positioning and competitive advantage (post-case) }\end{array}$ & $0.0 \%$ & $3.4 \%$ & $26.7 \%$ & $61.6 \%$ & $8.2 \%$ & 3.75 & \\
\hline 5 & The case was interesting (post-case) & $0.0 \%$ & $2.7 \%$ & $32.0 \%$ & $49.0 \%$ & $16.3 \%$ & 3.79 & \\
\hline 6 & The case was realistic (post-case) & $0.0 \%$ & $2.7 \%$ & $20.3 \%$ & $54.7 \%$ & $22.3 \%$ & 3.97 & \\
\hline 7 & The case was relevant to our course (post-case) & $0.0 \%$ & $0.0 \%$ & $8.1 \%$ & $61.5 \%$ & $30.4 \%$ & 4.22 & \\
\hline 8 & The case and related questions were too difficult (post-case) & $5.4 \%$ & $37.2 \%$ & $44.6 \%$ & $10.1 \%$ & $2.7 \%$ & 2.68 & \\
\hline 9 & I recommend using this case as part of the course in the future (post-case) & $0.7 \%$ & $1.4 \%$ & $27.0 \%$ & $50.7 \%$ & $20.3 \%$ & 3.89 & \\
\hline 10 & Overall the case was a valuable learning experience (post-case) & $0.0 \%$ & $0.7 \%$ & $18.2 \%$ & $63.5 \%$ & $17.6 \%$ & 3.98 & \\
\hline
\end{tabular}

***Significant at the 0.01 level; **Significant at the 0.05 level; *Significant at the 0.10 level (2-tailed) 
TABLE 7

Pre- and post-case completion data (Graduate, $n=320$ )

\begin{tabular}{|c|c|c|c|c|c|c|c|c|}
\hline Item & Question & $\begin{array}{l}\text { Strongly } \\
\text { disagree } \\
(1)\end{array}$ & $\begin{array}{l}\text { Disagree } \\
(2)\end{array}$ & $\begin{array}{l}\text { Neutral } \\
(3)\end{array}$ & $\begin{array}{l}\text { Agree } \\
(4)\end{array}$ & $\begin{array}{l}\text { Strongly } \\
\text { agree } \\
(5)\end{array}$ & Mean & $\begin{array}{l}\text { T-test } \\
(t \text {-stat })\end{array}$ \\
\hline 1a & I can recognize the important areas of cost in a service firm (pre-case) & $0.6 \%$ & $6.6 \%$ & $21.19 \%$ & $59.7 \%$ & $11.3 \%$ & 3.744 & $10.701 * * *$ \\
\hline $1 b$ & I can recognize the important areas of cost in a service firm (post-case) & $0.0 \%$ & $1.6 \%$ & $6.3 \%$ & $60.6 \%$ & $31.5 \%$ & 4.221 & \\
\hline $2 \mathrm{a}$ & I understand the purpose of target costing (pre-case) & $0.0 \%$ & $2.8 \%$ & $17.9 \%$ & $57.5 \%$ & $21.7 \%$ & 3.990 & $8.634 * * *$ \\
\hline $2 b$ & I understand the purpose of target costing (post-case) & $0.0 \%$ & $0.3 \%$ & $4.7 \%$ & $53.3 \%$ & $41.7 \%$ & 4.364 & \\
\hline $3 a$ & I can apply target costing to a service firm (pre-case) & $0.9 \%$ & $14.7 \%$ & $50.8 \%$ & $30.7 \%$ & $2.8 \%$ & 3.197 & $14.811^{* * *}$ \\
\hline $3 b$ & I can apply target costing to a service firm (post-case) & $0.0 \%$ & $2.2 \%$ & $26.2 \%$ & $53.3 \%$ & $18.3 \%$ & 3.877 & \\
\hline $4 a$ & $\begin{array}{l}\text { I can creatively consider service firm costs in the context of competitive } \\
\text { positioning and competitive advantage (pre-case) }\end{array}$ & $0.9 \%$ & $15.1 \%$ & $53.8 \%$ & $27.4 \%$ & $2.8 \%$ & 3.160 & $13.345 * * *$ \\
\hline $4 \mathrm{~b}$ & $\begin{array}{l}\text { I can creatively consider service firm costs in the context of competitive } \\
\text { positioning and competitive advantage (post-case) }\end{array}$ & $0.0 \%$ & $2.8 \%$ & $26.6 \%$ & $56.7 \%$ & $13.8 \%$ & 3.815 & \\
\hline 5 & The case was interesting (post-case) & $0.0 \%$ & $3.5 \%$ & $21.8 \%$ & $43.8 \%$ & $30.9 \%$ & 4.022 & \\
\hline 6 & The case was realistic (post-case) & $0.3 \%$ & $1.6 \%$ & $8.8 \%$ & $52.8 \%$ & $36.5 \%$ & 4.236 & \\
\hline 7 & The case was relevant to our course (post-case) & $0.6 \%$ & $1.3 \%$ & $6.6 \%$ & $50.6 \%$ & $40.8 \%$ & 4.297 & \\
\hline 8 & The case and related questions were too difficult (post-case) & $2.2 \%$ & $26.4 \%$ & $50.9 \%$ & $16.7 \%$ & $3.8 \%$ & 2.934 & \\
\hline 9 & I recommend using this case as part of the course in the future (post-case) & $0.3 \%$ & $2.5 \%$ & $21.3 \%$ & $57.4 \%$ & $18.5 \%$ & 3.912 & \\
\hline 10 & Overall the case was a valuable learning experience (post-case) & $0.0 \%$ & $0.9 \%$ & $10.0 \%$ & $57.7 \%$ & $31.3 \%$ & 4.194 & \\
\hline
\end{tabular}

***Significant at the 0.01 level; **Significant at the 0.05 level; *Significant at the 0.10 level (2-tailed) 


\section{TABLE 8}

Pre- and post-case quiz questions 1-5 comparisons using Wilcoxon signed ranks test $(n=40)$

\begin{tabular}{|c|c|c|c|c|c|}
\hline Item & Question & Correct answer & $\begin{array}{l}\% \text { Pre-case } \\
\text { quiz } \\
\text { correctness }\end{array}$ & $\begin{array}{l}\% \text { Post-case } \\
\text { quiz } \\
\text { correctness }\end{array}$ & Z-statistic \\
\hline 1 & $\begin{array}{l}\text { As a proportion of overall costs, which firm (choose one) } \\
\text { do you most expect has the highest proportion of fixed costs } \\
\text { compared to total costs (fixed and variables cost) }\end{array}$ & Service firm & $25.6 \%$ & $51.3 \%$ & $2.236^{* *}$ \\
\hline 2 & $\begin{array}{l}\text { Which cost would be more significant in a service firm (a } \\
\text { higher proportion of total cost) when compared to a } \\
\text { manufacturing firm? }\end{array}$ & Direct labor costs & $61.5 \%$ & $69.2 \%$ & 0.728 \\
\hline 3 & $\begin{array}{l}\text { Cost-plus pricing involves calculating a total product cost } \\
\text { and adding a desired profit margin to determine the selling } \\
\text { price. Which of the following is the most problematic } \\
\text { assumption of cost-plus pricing? }\end{array}$ & $\begin{array}{l}\text { The customer will accept any price set } \\
\text { by the firm for its product or service }\end{array}$ & $46.2 \%$ & $74.4 \%$ & $2.524 * *$ \\
\hline 4 & $\begin{array}{l}\text { Allowable costs under target costing would include which } \\
\text { of the following cost elements }\end{array}$ & Direct and overhead costs & $43.6 \%$ & $53.8 \%$ & 1.000 \\
\hline 5 & $\begin{array}{l}\text { Target costing approaches are more useful than cost-plus } \\
\text { pricing approaches because: }\end{array}$ & $\begin{array}{l}\text { Target costing is a strategic approach } \\
\text { that starts with an understanding of the } \\
\text { product or service features and how } \\
\text { much customers are willing to pay for } \\
\text { them }\end{array}$ & $76.9 \%$ & $97.4 \%$ & $2.530 * *$ \\
\hline
\end{tabular}




\section{TABLE 9}

Pre- and post-case quiz question 6-9 mean rank comparisons using Wilcoxon signed ranks test $(n=40)$

Panel A: Questions 6 - Rank the significance of the following costs from 1 (highest cost) to 4 (lowest cost) in determining the total costs of a service firm compared with a manufacturing firm

\begin{tabular}{lcccl}
\hline & Cost of goods sold & Marketing & Salaries \& wages & $\begin{array}{l}\text { Depreciation \& } \\
\text { leasing equipment }\end{array}$ \\
\hline Pre-case quiz & 2.775 & 2.125 & 1.750 & 3.350 \\
Post-case quiz & 3.250 & 2.175 & 1.200 & 3.350 \\
$Z$-statistic & $2.506^{* *}$ & 0.323 & $-3.370^{* * *}$ & -0.065 \\
\hline
\end{tabular}

Panel B: Questions 7 - Rank the importance of the following considerations for firm management from most important (1) to least important (4)

\begin{tabular}{lcccc}
\hline & $\begin{array}{l}\text { Calculating the } \\
\text { total product cost }\end{array}$ & $\begin{array}{l}\text { Determining the } \\
\text { product price the } \\
\text { market will accept }\end{array}$ & $\begin{array}{l}\text { Determining the } \\
\text { gross profit margin }\end{array}$ & $\begin{array}{l}\text { Determining target } \\
\text { net profit }\end{array}$ \\
\hline Pre-case quiz & 2.103 & 2.256 & 2.718 & 2.923 \\
Post-case quiz & 3.282 & 1.359 & 2.667 & 2.692 \\
$Z$-statistic & $3.863^{* * *}$ & $-3.307^{* * *}$ & -0.329 & -0.768 \\
\hline
\end{tabular}

Panel B: Questions 8 -To ensure the ongoing survival of a firm, rank the importance of the following factors from most important (1) to least important (4)

\begin{tabular}{llccc}
\hline & $\begin{array}{l}\text { Minimizing all } \\
\text { costs to maximize } \\
\text { net profit }\end{array}$ & $\begin{array}{l}\text { Prioritizing costs in } \\
\text { the interests of } \\
\text { delivering on } \\
\text { competitive } \\
\text { strategy }\end{array}$ & $\begin{array}{l}\text { Determining an } \\
\text { adequate gross } \\
\text { profit margin and } \\
\text { adding this to total } \\
\text { product costs }\end{array}$ & $\begin{array}{l}\text { Using the target } \\
\text { profit as the main } \\
\text { determining factor } \\
\text { of product pricing }\end{array}$ \\
\hline $\begin{array}{l}\text { Pre-case quiz } \\
\text { Post-case quiz }\end{array}$ & 2.750 & 2.275 & 2.450 & 2.525 \\
Z-statistic & 1.025 & 2.150 & 2.425 & 2.425 \\
\hline
\end{tabular}

Panel B: Questions 9 - Rank the challenges of managing a service firm from most (1) to least challenging (4) relative to managing a manufacturing firm

\begin{tabular}{llccc}
\hline & $\begin{array}{l}\text { The service sector } \\
\text { is very competitive }\end{array}$ & $\begin{array}{l}\text { Fixed costs as a } \\
\text { proportion of total } \\
\text { product cost }\end{array}$ & $\begin{array}{l}\text { Variable costs as a } \\
\text { proportion of total } \\
\text { product cost }\end{array}$ & $\begin{array}{l}\text { Prioritizing } \\
\text { different costs to } \\
\text { delivery on } \\
\text { competitive } \\
\text { strategy }\end{array}$ \\
\hline Pre-case quiz & 2.075 & 3.100 & 2.600 & 2.225 \\
Post-case quiz & 2.225 & 2.825 & 2.950 & 2.000 \\
$Z$-statistic & 0.569 & -1.066 & $1.676^{*}$ & -0.885 \\
\hline
\end{tabular}

$* * *$ Significant at the 0.01 level; $* *$ Significant at the 0.05 level; $*$ Significant at the 0.10 level 
TABLE 10

Pre- and post-quiz open-ended questions 10-12 coding comparisons using Wilcoxon signed ranks test $(n=40)$

\begin{tabular}{|c|c|c|c|c|c|}
\hline Item & Question & Response coding & $\begin{array}{l}\% \text { Pre-quiz } \\
\text { code } 1\end{array}$ & $\begin{array}{l}\% \text { Post-quiz } \\
\text { code } 0\end{array}$ & $Z$-statistic \\
\hline 10 & $\begin{array}{l}\text { List the key steps involved in determining a target cost. } \\
\text { Number each of these steps from first through to last. }\end{array}$ & $\begin{array}{l}\text { Code } 1 \text { for list commencing with a focus } \\
\text { on market expectations and/or pricing, } 0 \\
\text { otherwise }\end{array}$ & $78.9 \%$ & $100.0 \%$ & $2.646 * * *$ \\
\hline 11 & $\begin{array}{l}\text { Describe how a service firm could manage its product costs } \\
\text { to bring these in line with allowable costs? }\end{array}$ & $\begin{array}{l}\text { Code } 1 \text { for answer focusing on value } \\
\text { generation for customers, } 0 \text { otherwise }\end{array}$ & $15.2 \%$ & $65.8 \%$ & $3.128 * * *$ \\
\hline 12 & $\begin{array}{l}\text { How will a target costing approach help improve } \\
\text { competitive advantage for a service firm? }\end{array}$ & $\begin{array}{l}\text { Code } 1 \text { for answer focusing on value } \\
\text { drivers for customers }\end{array}$ & $41.2 \%$ & $65.0 \%$ & $2.496 * *$ \\
\hline
\end{tabular}

***Significant at the 0.01 level; **Significant at the 0.05 level; *Significant at the 0.10 level 
TABLE: TEACHING NOTES

Table 1: Alternative scenario

\begin{tabular}{|c|c|c|c|c|}
\hline Cost item & $\begin{array}{l}\text { Cost per unit } \\
\text { (average \$) }\end{array}$ & $\begin{array}{l}\text { No. of } \\
\text { units }\end{array}$ & $\begin{array}{l}\text { Total } \\
(\$)\end{array}$ & $\begin{array}{l}\text { Percentage } \\
(\%)\end{array}$ \\
\hline \multicolumn{5}{|l|}{ Salaries \& wages: } \\
\hline Underwriting salaries (FT salary including on costs) & 57,963 & 13 & 753,519 & 12.3 \\
\hline $\begin{array}{l}\text { Underwriting commission per policy ( } 10 \% \text { of annual } \\
\text { premium) }\end{array}$ & 240 & 1,250 & 300,000 & 4.9 \\
\hline $\begin{array}{l}\text { Claims and administration staff (FT salary including } \\
\text { on costs) }\end{array}$ & 51,843 & 14 & 725,802 & 11.8 \\
\hline $\begin{array}{l}\text { Management salaries and bonuses (FT salary } \\
\text { including on costs) }\end{array}$ & 125,250 & 4 & 501,000 & 8.2 \\
\hline $\begin{array}{l}\text { Marketing staff salaries (FT salary including on } \\
\text { costs) }\end{array}$ & 75,698 & 4 & 302,792 & 4.9 \\
\hline \multicolumn{5}{|l|}{ Training: } \\
\hline Underwriting training program for new staff & 4,750 & 2 & 9,500 & 0.2 \\
\hline Claims management program for new staff & 3,250 & 2 & 6,500 & 0.1 \\
\hline \multicolumn{5}{|l|}{ Marketing: } \\
\hline TV (cost per campaign) & 179,742 & 1 & 179,742 & 2.9 \\
\hline Billboards & 15,121 & 35 & 529,235 & 8.6 \\
\hline Online advertising including social media & & & 34,564 & 0.6 \\
\hline Event representations (trade stall and setup cost) & 8,700 & 10 & 43,852 & 0.7 \\
\hline \multicolumn{5}{|l|}{ Technology: } \\
\hline Software/information systems subscriptions & & & 45,000 & 0.7 \\
\hline Webpage setup and maintenance & & & 15,000 & 0.2 \\
\hline \multicolumn{5}{|l|}{ Leasing: } \\
\hline $\begin{array}{l}\text { Computer leases (across all Sunline insurance } \\
\text { operations) }\end{array}$ & & & 43,150 & 0.7 \\
\hline Retail store leases & 60,000 & 16 & 960,000 & 15.6 \\
\hline Sunline main office lease & & & 72,500 & 1.2 \\
\hline \multicolumn{5}{|l|}{ Insurance costs: } \\
\hline Claims & & & 932,432 & 15.2 \\
\hline Roadside assistance callout charge & 250 & 1,611 & 402,750 & 6.6 \\
\hline Headquarter charge back & & & 306,467 & 5.0 \\
\hline $\begin{array}{l}\text { Interest earnings on cash provision for insurance } \\
\text { claims }\end{array}$ & & & $(25,000)$ & $(0.4)$ \\
\hline Total costs & & & $6,138,805$ & $100 \%$ \\
\hline Target cost & & & $6,216,620$ & \\
\hline
\end{tabular}

FT: Fulltime 